\title{
State Bank Transformation in Brazil - Choices and
}

\author{
Consequences
}

\author{
Thorsten Beck, Juan Miguel Crivelli and William Summerhill
}

\begin{abstract}
This paper analyzes the different options - liquidation, federalization, privatization and restructuring - that the Brazilian state government had for the transformation of state banks under the Programa de Incentivo á Redução do Setor Público Estadual na Atividade Bancária (PROES) in the late 1990s. Specifically, the paper explores (i) the factors behind the states' choices and (ii) the effects of the transformation process on bank performance and efficiency. We find that states that were more dependent on federal transfers, whose banks were already under federal intervention and that established development agencies were more likely to relinquish control over their banks and transformation processes. We find that privatized banks improved their performance, while restructured banks did not.
\end{abstract}

Keywords: Bank privatization; Brazil; bank performance

JEL Classification: G21 ; G28 ; H77

World Bank Policy Research Working Paper 3619, June 2005

The Policy Research Working Paper Series disseminates the findings of work in progress to encourage the exchange of ideas about development issues. An objective of the series is to get the findings out quickly, even if the presentations are less than fully polished. The papers carry the names of the authors and should be cited accordingly. The findings, interpretations, and conclusions expressed in this paper are entirely those of the authors. They do not necessarily represent the view of the World Bank, its Executive Directors, or the countries they represent. Policy Research Working Papers are available online at http://econ.worldbank.org.

Beck and Crivelli: World Bank; Summerhill: University of California at Los Angeles. We are grateful to Fernando Blanco, Robert Cull, George Clarke, Phil Keefer, Anjali Kumar, Marcio Nakane, Alvaro Vivanco, and an anonymous referee for useful suggestions and discussions, and to Duillo Pighi for excellent research and editorial assistance. We also benefited from comments by participants at the World Bank Conference on Bank Privatization and ISNIE 2004. 


\section{Introduction}

While Gerschenkron suggested that the state-as-banker could overcome a legacy of poor financial intermediation, substitute for the absence of private banks, and impel economic growth in poorer nations, government ownership of banks is in fact closely associated with an ensemble of problems that afflict developing countries: low levels of GDP per capita, financial backwardness, and a heavy and inefficient state sector (La Porta et al, 2001, Barth. Caprio and Levine, 2004; Dinc, 2005). Privatization of government-owned banks could thus be expected to improve bank performance, and boost the efficiency of financial intermediation.

This paper analyzes the transformation of state banks in Brazil, where banks owned by state governments have undergone a remarkable process of reform in the last decade. It (i) evaluates how states chose between different options they were given by a federal government transformation program, and (ii) assesses the effect of privatization, federalization and restructuring on the subsequent performance of the state banks. We test for financial, economic and political determinants of the choices made by state governments concerning their state banks. We then evaluate the impact of the different choices on bank performance and compare the effects of the different policy choices with each other.

State-owned banks have a long tradition in Brazil, as have their financial problems (see Ness, 2000, for a historic overview). During the decades before 1994 the Central Bank came to their rescue in several instances, bailing them out. Bailouts directly resulted in monetary leakages and high moral hazard risk in the relationship both between the federal and state governments, and between the Central-Bank-as-bank-supervisor and the banking system. Following the implementation of the Real Plan in 1994, which helped considerably in ending 
hyperinflation, federal authorities addressed the chronic undercapitalization and continuing losses of state banks to avoid future monetary leakages through bailouts. After intervening in several state banks in 1994 and 1995, the federal government initiated a special program, the Programa de Incentivo á Redução do Setor Público Estadual na Atividade Bancária (PROES), to allow restructuring, privatization or liquidation of state banks. States were given a range of choices concerning the future of their banks, linked closely to the terms of debt relief by the federal government.

Under PROES, states had effectively four choices concerning the future of their state banks. They could (i) liquidate, (ii) allow the federal government to privatize, (iii) privatize themselves, or (iv) restructure them. Under the first three options, the federal government assumed $100 \%$ of any losses that occurred during the process, while it assumed $50 \%$ of the losses under the restructuring option. Further, states had the option to set up or split off a development agency. However, states could also opt out of the PROES program. These options implied different degrees to which state government gave up control over (i) the bank itself and (ii) the process under which the bank was resolved or restructured. Depending on one's point of departure, several competing hypotheses regarding the possible determinants of this choice are available. Political economy models predict a trade-off between the benefits of having the state bank as a patronage tool (or using the privatization process to impose conditionality on the buyer) and the fiscal costs of continuous losses. Unlike in the period before 1994, under PROES these losses could no longer be externalized to the federal government. Development theories predict a relationship between the perceived need for state involvement in the financial sector, and the state's willingness or reluctance to give up control over its bank. Political scientists would predict the relationship and political alignment 
between the state and federal level of government to be a decisive factor behind the PROES decisions. The options under PROES, however, can also be expected to have different consequences for operational and financial restructuring and thus the subsequent performance of these banks.

The two questions addressed in this paper are important for both academics and policymakers. First and most generally, the results help us assess the effect of bank privatization on performance and compare it with the effects of restructuring and staying in government ownership. These results can inform policymakers in Brazil and other countries with fragile government banks. Second, the results help us evaluate different approaches to privatization, specifically, intervention and subsequent privatization by the federal government versus privatization by the original owner, the state government. Third, they help us understand the factors behind the political process of bank privatization, and ultimately the determinants of continued government ownership of banks around the globe.

The Brazilian PROES offers us a natural experiment to study the determinants and consequences of a state bank resolution program. The process was started by an event, the Real Plan, which was outside the control of any individual state and not primarily caused by the undercapitalization of state banks. The large number of banks that were resolved over a short time period - all but two states owned banks -, a relatively equal distribution of banks across the different policy alternatives and the variation in economic and political structure across states allow us to relate variation in the political and economic structure of states to the political decision on their banks, and to relate subsequent performance of these banks to the different choices states made. 
Data shortages and the short time that has passed since the implementation of PROES limit our analysis. First, although states decided on the transformation options at different points in time, we assess states' choices in a cross-section rather than taking into account the dynamic aspects. Second, we restrict our evaluation of the PROES to bank performance, rather than assessing the impact on economic and financial development on the state level; given that some state banks have been privatized only recently and some federalized state banks have not yet been privatized, such an analysis would reduce the degrees of freedom substantially. Third, we face a selection bias since the state banks that were liquidated or converted into development agencies are not included in the bank-level sample that we use to assess their performance. Finally, the bank-level data that are available do not allow us to test more sophisticated models of profit and cost efficiency.

Our results provide support for political economy theories of public ownership, while they are inconsistent with developmental hypotheses. States that were more dependent on federal transfers, whose banks were already under federal intervention, and that established development agencies were more likely to relinquish control over their banks and the transformation process. We find significant and positive effects of privatization on banks' performance, while we cannot find similar improvements for banks that restructured. In only a few cases, however, did these performance improvements go beyond the performance of privately owned domestic banks.

This paper is closely related to two papers by Clarke and Cull $(1999,2002)$ on the Argentine privatization process of provincial banks. Similar to Brazil, the Argentine privatization process started after an exogenous event, i.e. an event outside the control of individual states, that made further federal subsidization of provincial banks impossible, and 
also happened during a relatively short time period. Unlike the Brazilian case, the Argentine provinces faced only the option of privatization to receive federal funding. Analyzing the timing of the privatization, Clarke and Cull find that - consistent with political economy models of privatization - provinces with poorly performing banks and thus higher costs of government ownership were more likely to privatize their banks, while those provinces where politicians could derive higher benefits showed a lower probability of privatization. Clarke and Cull also find performance and efficiency improvements, post-privatization.

This paper is also related to Baumohl and Nakane (2005) who use a model developed by Olley and Pakes (1996) to assess the effect bank privatization on bank productivity. Unlike them we analyze a broader range of PROES options and also evaluate the factors behind the different PROES options.

The remainder of the paper is organized as follows. Section 2 offers background information on Brazil's banking system and the privatization process. Section 3 tests different hypotheses on the state government's decisions on their banks under PROES. Section 4 describes the data and the methodology for the bank-level performance regressions. Section 5 presents the results of the bank-level regressions and section 6 concludes.

\section{Bank privatization in Brazil}

One of the more remarkable features of Brazil's move toward privatization in the 1990s was the progressive dismantling of debt-ridden state banks. State banks were an important segment of the public bank sector; state-owned and federally-owned banks together constituted over 50\% of overall banking system assets in 1994 (Table 1). Some of the state banks were also among the largest Brazilian banks. BANESPA, owned by the state 
government of São Paulo, ranked third in terms of assets in 1994, while the other São Paulo state bank, Nossa Caixa, ranked $11^{\text {th }}$. The roots of these banks, both historically and politically, ran deep in Brazil, which has a long tradition of such financial institutions. Banks owned by state governments appeared during the First Republic (1889-1930), and multiplied over the course of the twentieth century. ${ }^{1}$ Their ostensible purposes included handling publicsector payrolls, and financing state-level development projects. Yet they increasingly came to serve as major instruments of state-level deficit financing. ${ }^{2}$ State banks were a critical component in the machinery of generating employment, patronage, and securing electoral support. ${ }^{3}$ Since the costs of these activities were spread broadly, while the banks' benefits were concentrated more narrowly, they were politically valuable instruments.

By the end of Brazil's military dictatorship in the mid 1980s most state banks were in dire straits. State banks had repeatedly relied on the Central Bank and state coffers to relieve them of liabilities or to recapitalize them. ${ }^{4}$ In the context of worsening economic conditions and public sector deficits a disproportionate share of state bank income derived from inflation-based revenues. ${ }^{5}$ Banks used short-term deposits imperfectly protected from inflation to purchase securities that yielded much higher rates of interest than were paid to depositors. ${ }^{6}$ Inflation-float revenue became a key source of bank earnings for the Brazilian banking sector as a whole, and especially important for state banks.

\footnotetext{
${ }^{1}$ Baer and Nazmi (2000), 5.

${ }^{2}$ Ness (2000), 72; Baer and Nazmi (2000), 7; McQuerry (2001), 38; Maia (1999), 115.

${ }^{3}$ Baer and Nazmi (2000), 7.

${ }^{4}$ Ness (2000), 75. Compare Sola, Garman and Marques (2001) and Lundberg (1999) for a detailed discussion on the use of the monetary reserve by the Central Bank to bail out state banks in the 1980s and 1990s.

${ }^{5}$ McQuerry (2001), 38.

${ }^{6}$ Baer and Nazmi (2000), 6; Ness (2000), 75.
} 
The Brazilian government introduced its inflation-defeating monetary reform, known as the Real Plan, in July of $1994 .^{7}$ By eliminating price inflation in a setting where inflation sometimes ran as high as 70 percent per month the plan also eliminated the easiest way that banks made money. ${ }^{8}$ Bank revenues that hinged on inflation-based “float” earnings dried up, falling from 35 percent of sectoral revenues to effectively zero between 1993 and $1995 .{ }^{9}$ In response, banks increased their lending business, without adequate risk analysis and information on borrowers, and without adequate bank supervision by the Central Bank. As the government defended the currency and real interest rates skyrocketed, indebted businesses increasingly failed, and banks found themselves holding an increasing share of nonperforming loans, including those made to state-owned companies. Numerous Brazilian banks, both public and private, became increasingly fragile. The ensuing interventions in state banks by the Central Bank, beginning at the end of 1994, were part and parcel of a broader clean up of the banking sector. They differed from interventions in private banks, however, in that reducing the presence of state governments in the banking sector formed part of larger debt settlement arrangements between states and the federation. ${ }^{10}$

Central bank led reforms of state banks came in two main phases. The first saw interventions in the largest and most problem-ridden state banks at the end of 1994 and early 1995. Existing legislation empowered the Central Bank to intervene in banks, liquidate banks extra-judicially, and place banks under special temporary management (Regime de Administração Especial Temporária-RAET). ${ }^{11}$ The second phase came with the late 1996 decree of the Program of Incentives for the Reduction of States’ Participation in Banking

\footnotetext{
${ }^{7}$ Franco (1995); Franco (2000).

${ }^{8}$ McQuerry (2001), 33.

${ }^{9}$ Mendonca de Barros, et al. (1997); Maia (1999); Baer and Nazmi (2000), 8.

${ }^{10}$ Maia (1999), 116-117; Baer and Nazmi (2000), 14.

${ }^{11}$ Lundberg (1999); Siqueira (n.d.).
} 
Activities (Programa de Incentivo á Redução do Setor Público Estadual na Atividade

Bancária-PROES). PROES created mechanisms by which state governments could repair or dispose of their banks with federal resources, and has served as the basis for most of the state bank reforms to date. ${ }^{12}$

Intervention of the Central Bank in state banks in the first phase under RAET differed from simple intervention and extra-judicial liquidation in that the normal activities of the state banks continued unaltered. During the period that RAET is in effect (which is flexible and at the discretion of the Central Bank), depositors are protected. At the end of 1994 (on the eve of newly elected governors from the President-elect's own party (PSDB) taking office in the states of Rio de Janeiro and São Paulo), the Central Bank intervened using RAET in both BANERJ and BANESPA, two of the largest and most indebted banks. ${ }^{13}$ Public authorities were careful to stress that intervention was being conducted in accordance with RAET, and promised the preservation of the accounts of depositors. Pedro Malan, president of the Central Bank, asserted that "anyone who wants to go to the banks on Monday to take out their money will encounter plenty of cash at their disposal."14 All told, five state banks were placed under RAET through $1995 .^{15}$ Some other state financial entities were liquidated outright; at the same time Central Bank intervened in BANERJ and BANESPA, it also closed a relatively small bank in the state of Rio Grande do Norte. ${ }^{16}$

\footnotetext{
${ }^{12}$ PROES followed on the heels of a similar program to restructure or close troubled private-sector banks, known as PROER. Some of the state banks that underwent early intervention were actually privatized under PROER, rather than PROES.

${ }^{13}$ Folha de São Paulo, 31 Dec 1994.

${ }^{14}$ Ibid., 5.

${ }^{15}$ Maia (1999), 111; in addition to BANERJ and BANESPA, state banks in Alagôas, Mato Grosso, and Rondônia were placed under RAET; Ness (2000), 77.

${ }^{16}$ Folha de São Paulo, 31 Dec 1994, 1-2. Later the state bank of Amapá was liquidated by the Central Bank, without recourse to the Regime of Special Temporary Administration. Though the bank's liabilities were only modestly in excess of its assets, it had fraudulently issued nearly six billion dollars' worth of bonds that were
} 
The second phase of state bank reforms came with the implementation of the 1996 PROES decree in early 1997. Like intervention under RAET, PROES safeguarded depositors while the state bank's final fate was being determined. It differed from RAET, however, in that it was part of a broader program to address state government debts. ${ }^{17}$ In 1997 and 1998 22 out of 27 states in Brazil renegotiated their debt with the federal government, and the disposition of state banks was a central element of the renegotiations. ${ }^{18}$ Debt restructuring was done in a way that allowed state banks to swap state-government bonds for federal bonds. The level of state debt was then reduced by the federal government, which created a considerable subsidy in the form of accepting below-market interest rates on the state bonds they acquired. ${ }^{19}$ Overall, the refinanced debt varied between 1\% of state GDP and 19\% of state GDP. While there were no penalties for not participating in PROES, the dire straits in which the finances of many states were and the weak financial situation of most state banks gave sufficient incentives for all but two states to participate. Furthermore, if deciding not to participate in PROES, the state government would be liable for any future losses of its $\operatorname{bank}(\mathrm{s}) .^{20}$

Under PROES, there were four possible policy options for a state bank. These were 1) liquidation; 2) submission to federal control for subsequent liquidation or privatization; 3) privatization under state auspices; and 4) restructuring and continuation as a state bank. Additionally, states had the options to set up or split off from a privatized or liquidated bank a development agency. Funding to these development agencies can be provided only by other

collateralized by a huge land tract of uncertain title. Forgeries of signatures of Central Bank officials were discovered on the deal, and the Central Bank liquidated the bank; Folha de São Paulo, 4 Sep 97, 10.

${ }^{17}$ Bevilacqua (1999); Ness (2000).

${ }^{18}$ The states that did not participate were mostly recently created states without significant outstanding debt.

${ }^{19}$ See Maia (1999), 116, and Bevilaqua (1999) for more details.

${ }^{20}$ Under Brazilian law, bank shareholders are liable for any losses beyond paid-in capital. 
domestic or foreign development agencies, treasuries or constitutional funds, but not by deposits from the general public; these agencies are allowed to invest only in priority areas as defined by the state government. Privatized banks were sold to strategic investors, i.e. foreign or domestic private banks, with the state relinquishing all control; in some cases, however, up to $10 \%$ of the shares were reserved for bank employees. Given the traditional importance of state banks in deficit financing, and their politicized use by governors, the above mentioned list represents a likely inverse ranking of what state authorities desired as the outcome for their bank. However, the a-priori preferred option - restructuring a state bank and keeping it required that the state provide at least half of the restructuring costs and change management. ${ }^{21}$ For most state governments, recapitalizing their bank was likely considerably more costly than the political benefits they stood to lose when relinquishing control. ${ }^{22}$

Under PROES a good portion of Brazil’s public financial system has been restructured since 1997. Specific outcomes under PROES varied, and not only by state; since some states had more than one bank, outcomes varied by bank as well. Table 2 provides a summary of the status of each of the state banks. Two of the states-Mato Grosso do Sul and Tocantinshad no bank. All other states had at least one state-owned bank. The state of Paraíba opted out of PROES altogether, as did the Federal District. Seven states had more than one state financial institution. The state of Espírito Santo apparently had one bank under PROES, but was able to opt out with respect to its second bank. ${ }^{23}$ Six states were able to restructure a bank and keep it, including four states that had more than one bank, though Espírito Santo is currently attempting to privatize. Nine banks have been privatized to strategic investors; five

\footnotetext{
${ }^{21}$ The federal government also covered only $50 \%$ of the losses in the cases where the state government decided to privatize or liquidate one, but keep and restructure another state bank.

${ }^{22}$ Ness (2000), 80.

${ }^{23}$ Folha de São Paulo 12 May 2000.
} 
more banks are slated for privatization, but with no definite date set. The privatization and liquidation of state banks under PROES has contributed significantly to the decrease in government ownership in the Brazilian banking system. By end-1999 it has fallen to $43 \%$ of total assets. This decline has been accompanied by a significant increase in foreign participation in the Brazilian banking system (Table 1).

\section{PROES and the determinants of the different options}

While there is a large literature analyzing the politics of privatization of non-financial companies, there are few papers discussing the political decision process to privatize government-owned banks. ${ }^{24}$ We therefore build on the economics of state ownership of banks for our hypothesis testing on states’ different choices under PROES. ${ }^{25}$

To explore the factors behind the different methods of transformation of state banks, we construct a variable capturing the different options. Transformation equals one if the state bank was liquidated, two if the federal government took it over, three if the state government privatized it, and four if the bank was restructured and stayed in government ownership. This variable is structured in a way that higher values signify more decision power retained by the state government. ${ }^{26}$ However, the decision power of state government varied, since five state banks were already taken over by the Central Bank under the RAET before the PROES was

\footnotetext{
${ }^{24}$ On the politics of privatization in general, see Perotti (1995) and Biais and Perotti (2002). Boehmer et al. (2005) use a panel of 101 countries over the period 1982-2000 to analyze the determinants of bank privatization decisions, while Clarke and Cull (2002) assess the factors behind the timing of provincial bank privatization in Argentina.

${ }^{25}$ Compare La Porta et al. (2002).

${ }^{26}$ We also tried a simple dummy variable that takes value one if a bank is restructured and zero otherwise. The use of dummy variables as dependent and as independent variables (see below), however, posed econometric problems.
} 
initiated. We control for this factor with the dummy variable $R A E T .^{27}$ Finally, 15 states set up or split off development agencies from their state banks; we control for this by introducing the dummy variable $D F I$.

Political economy approaches predict that state governments assess the trade-off between (i) the political benefits of keeping their banks under state ownership to use them as patronage tools or at least keeping as much control over the resolution process as possible (by being able to impose certain conditions on the purchaser) and (ii) the fiscal costs of doing so. Additionally, many states faced a more imminent liquidity constraint. By offering to take over $100 \%$ of losses incurred during the resolution process, but only $50 \%$ if the state kept ownership over at least one bank, the federal government tipped the monetary balance against restructuring. This intuition provides us with our first set of hypotheses relating the economic conditions of the state and its bank to the character of the reform decision. States with larger fiscal deficits and more dependent on federal transfers would most likely be more inclined to accept the options of liquidating or privatizing their banks, since their budgets were less likely to support additional strain from accumulating state bank losses. This is especially true given the credit and financing constraints that many states faced. Transfers as share of total revenues varies between 7\% in São Paulo to 78\% in Amapa, while the fiscal balance varied between a surplus of 2.2\% of GDP in Maranhao to a deficit of 1.8\% of GDP in Acre. States with larger GDP per capita and lower poverty rates would be less willing to give up their banks, given that they have more fiscal resources or have a better institutional framework to limit the fiscal cost and economic distortions of state ownership in the banking system. State

\footnotetext{
${ }^{27}$ We also re-ran the regressions without the states whose bank was intervened under RAET and obtain the same results as reported below.
} 
banks with worse performance and lower efficiency would be more likely to be privatized or liquidated given their higher cost to the state's budget.

Theories focusing on the developmental character of state banks provide us with several other predictions about the relationship between a state's economic structure, and the government's willingness to give up its state bank. Unlike political economy theories, developmental theories do not see state banks as patronage tools to distribute benefits to narrow and small groups, but rather focus on their benefits for the overall economy and society. First, developmental theories would predict that poorer states - depending more on federal transfers - would be rather less willing to give up their banks, while richer states might have a better developed judicial and institutional framework to support private banking activity. ${ }^{28}$ Second, given the long tradition of providing agricultural credit through government-owned banks, these theories would also predict states with larger agricultural sectors to be less likely to give up their banks. Similarly, developmental theories would predict that state banks with more retail orientation would be less likely to be privatized or liquidated. ${ }^{29}$

Finally, political scientists stress the increasing interest of Brazilian politicians in developing reputations as leaders who could deliver the goods to the constituents of their states during the 1980s and 1990s. Elected office holders, whether they occupy a congressional seat and want to move to the state executive or the governor's office or want to maximize their reelection chances, focus their efforts on extracting as much as possible for their states from the federal government's common pool of resources. In the case of PROES, this would imply bargaining over different options. Politicians' success at pulling down

\footnotetext{
${ }^{28}$ Compare Pinheiro and Cabral (1998).

${ }^{29}$ Alternatively, one could argue that banks with stronger retail orientation have stronger political clout and can therefore more easily resist liquidation or privatization.
} 
resources for their states, however, depends at least in part on their ties to the president. The emphasis is on membership in either the President's party or coalition on the part of Senate delegations from each state. For each state's senate delegation we incorporate a measure of the proportion of the federal senators from each state that are members of the PSDB, and similarly the proportion that are members of parties included in the president's coalition. The relationship between these measures of political closeness to the Cardoso government and PROES decision, however, is not unambiguous. On the one hand, one could expect states whose senators are politically closer to the federal government are better able to negotiate to keep their banks or at least privatize themselves. On the other hand, one could expect states whose leaders were more closely tied to the ruling coalition in the federal government to more easily agree to liquidation or federalization in return for other political or fiscal benefits. We assess the explanatory power of political economy and developmental theories of government-owned banks by regressing Transformation on an array of economic, social and bank-level financial indicators. ${ }^{30}$ Given the ordinal character of Transformation, we employ an ordered probit model. ${ }^{31}$ We use data bank-level data for 1996 and state-level averaged over 1995 to 2000, assembled from different Brazilian data sources. ${ }^{32}$

\footnotetext{
${ }^{30}$ We do not include the two states without state banks and the Federal District, which opted out of the PROES, and did not privatize its bank. We do, however, include Paraiba, since it privatized its state bank, though outside the PROES; our results, however, are robust to its exclusion. We also include São Paulo as a case where bank privatization happened under the auspices of the federal government. For the regressions including bank-level performance indicators as explanatory variables, we lose observations since we do not have observations for most of the liquidated banks. In the cases where we have bank-level data for more than one state bank, we average these data for use in the ordered probit analysis.

${ }^{31}$ While the observed variable Transformation has only four outcomes, there is a continuous underlying unobserved variable, the political preference of state governments. Each outcome of Transformation corresponds to a specific range of political preferences. We use standard maximum likelihood estimation with heteroskedasticity-robust standard errors. In robustness tests, we also use the multinominal logit model, which yields the same results.

${ }^{32}$ The political, economic, and financial variables used here, and in subsequent sections, are elaborated in the paper's appendices.
} 
The results in Table 3 provide evidence for political economy explanations of the transformation process, but are not consistent with developmental explanations of the transformation process. The results indicate that states that depend more on federal transfers and that set up development agencies were more likely to relinquish control over their banks and over the transformation process. The federal government was both more burdened by high-transfer states, and likely exercised more leverage over them in debt renegotiations. Not surprisingly, banks that were already intervened under RAET in 1994 and 1995 were less likely to be restructured and then returned to the hands of the governor. All three variables do not only enter statistically significant, but are also of large economic significance. For example, moving from the $25^{\text {th }}$ to the $75^{\text {th }}$ percentile in transfers, predicts a 33-percentage point difference in the probability that a state decided to restructure its bank or not. ${ }^{33}$

Most of the social and political variables do not enter significantly. Whether a state was rich or poor does not appear to matter to the outcome. Neither GDP per capita, the share of state output originating in agriculture, nor the poverty rate enter significantly. Nor do any characteristics of the bank's performance seem to matter for how it was dealt with. None of the bank efficiency measures nor our indicator of retail orientation - the share of savings deposits in total assets-- enter significantly in the regression. Finally, only one of the partisan political variables enters significantly. The share of the state's federal senate delegation that belonged to the president's party enters negatively at the $5 \%$ level, while the share of the senate delegation that belongs to one of the government coalition parties does not enter

\footnotetext{
${ }^{33}$ We also tested whether states that renegotiated a larger share of their debt with the federal government or had a larger share forgiven, were more likely to liquidate their state bank or have it federalized. However, we could not find a significant relationship between the outcome of the debt negotiations and the policy chosen for the state bank.
} 
significantly. ${ }^{34}$ The results here indicate that the closer the state's congressional delegation was to the president, the more likely the state bank was to be liquidated or privatized. This suggests that the executive might have found it easier to do away with state banks in states where he had stronger ties to the congressional delegates, perhaps because they could be compensated with political currency more readily. The executive simultaneously wielded greater punitive powers within the party as well if party members opposed the elimination of the state bank.

These results have to be interpreted with an important caveat. The small number of observations does not allow us to control for many different factors simultaneously. Idiosyncratic differences between the states are not captured in our regression. Finally, the time dimension, the fact that the states did not take the decision simultaneously is not explicitly modeled in our regressions. ${ }^{35}$

\section{Bank-level regressions: data and methodology}

In order to assess the performance and efficiency effects of the different PROES options, we utilize an unbalanced panel of 207 banks with quarterly data over the period January 1995 to September 2003, with a total of 4,864 observations. Our sample contains 19 of the 35 state banks. These banks were federalized, privatized and restructured at different points during our sample period. Liquidated state banks are not included. Further, we had to drop several banks for which we have incomplete data.

\footnotetext{
${ }^{34}$ In regressions we do not report here, we also tried measures of the share of a state's delegation in the House that belonged to the PSDB (the government coalition). Further, we used a dummy variable indicating whether a state's governor was member of the PSDB (one of the parties of the government coalition). In line with the results in Table 3, we find that states with a higher share of PSDB deputies or a governor belonging to one of the parties supporting the Cardoso government were more likely to liquidate their state banks or have it federalized. ${ }^{35}$ Compare Clarke and Cull (2002) on Argentina.
} 
We focus on three performance measures. Return on Equity (ROE) is defined as profits relative to equity, while Return on Assets (ROA) is profits relative to total assets. Overhead costs/assets are the total administrative costs relative to total assets. The first two indicators are measures of profitability, while the third one is a measure of cost efficiency.

There is a wide variation in performance and efficiency across banks and over time (Table 4 Panel A). ROE and ROA vary between high negative and positive outliers, with averages of -13 and zero percent respectively. In the case of the return on equity, however, this is driven by the negative outliers; the median is $3 \% .{ }^{36}$ Overhead costs relative to total assets vary between zero and $69 \%$, with a mean of $2 \%$ and a median of $1 \%$. Banks with higher overhead costs show lower profitability (Table 4 Panel B). ${ }^{37}$

To assess the effect of privatization on bank performance, while controlling for other bank characteristics, we utilize the following regression ${ }^{38}$ :

$$
\text { Performance }_{\mathrm{i}, \mathrm{t}}=\alpha+\beta_{1} \text { Assets }_{\mathrm{i}, \mathrm{t}-1}+\beta_{2} \text { Fixed Assets }_{\mathrm{i}, \mathrm{t}}+\beta_{3} \text { Savings Deposits }_{\mathrm{i}, \mathrm{t}}+
$$

$\beta_{4}$ Eventually Federalized and Privatized $_{\mathrm{i}, \mathrm{t}}+\beta_{5}$ Federalized before Privatization $_{\mathrm{i}, \mathrm{t}}+$ $\beta_{6}$ Privatized after Federalization $_{i, t}+\beta_{7}$ Time since Privatization after Federalization + $\beta_{8}$ Eventually Privatized $_{\mathrm{i}, \mathrm{t}}+\beta_{9}$ Privatized $_{\mathrm{i}, \mathrm{t}}+\beta_{10}$ Time since Privatization $+\beta_{11}$ Eventually

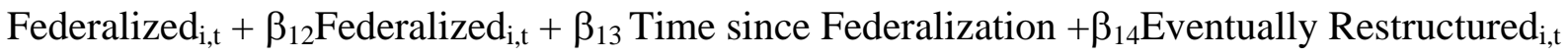

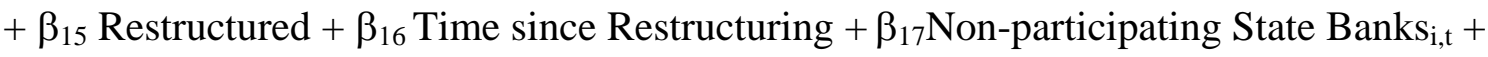
$\beta_{18}$ Federal Bank $\mathrm{i}_{\mathrm{i}, \mathrm{t}}+\beta_{19}$ Foreign Bank $_{\mathrm{i}, \mathrm{t}}+\varepsilon_{\mathrm{i}, \mathrm{t}}$

\footnotetext{
${ }^{36}$ The high negative outliers in the case of ROE are also explained by the following adjustment we make in the case of negative equity: we set equity at $1 \%$ of assets to avoid that a bank with negative equity and losses shows a positive ROE.

${ }^{37}$ Note that these are quarterly data. For annualized data, these would have to be multiplied by four. Since we use a linear estimation model, there is only a scaling effect.

${ }^{38}$ Similar models are employed by Berger et al. (2005) and Beck et al. (2005).
} 
where Performance is one of three variables measuring the performance of bank $i$ in quarter $t$. Those variables include return on equity (ROE), return on assets (ROA), and the ratio of overhead costs to total assets.

We use a vector of explanatory variables to de-compose the causes and effects of privatization. The first is Eventually Privatized, a dummy variable that equals one throughout the whole sample for state banks that were privatized by the state government at some point. We include this variable to capture any selection effect associated with bank privatization and with the choice of privatization by the state governments. The second is Privatized, a dummy variable that equals one from the moment bank $\mathrm{i}$ is privatized. We define privatization as the quarter in which the state government relinquishes ownership. The third variable is Time since Privatization, which measures the years since bank i was privatized. While Privatized is included to capture the immediate effects of privatization, including any cleaning of the loan portfolio at or just prior to the time of sale, Time since Privatization captures the average quarterly performance trend in the wake of that sale. To statistically assess the effect of privatization after quarter $n$, we evaluate Privatized $+n *$ Time since Privatization. While the use of several dummy variables might seem very complex, it helps separate the effect of privatization on performance properly by controlling for selection bias.

The second vector is for banks that were federalized and subsequently privatized. To assess selection bias and the effects of federalization and privatization, we construct three variables: Eventually Federalized and Privatized, Federalized before Privatization, and Privatized after Federalization, where the second and the third variables are timed for the quarters in which the federal government took responsibility for the bank and in which the 
government relinquished ownership, respectively. Finally we introduce a variable Time since Privatization after Federalization, which is defined similarly as above.

The third vector is for banks that were federalized, but have not been privatized yet. Here we construct the variables Eventually Federalized, Federalized, and Time since Federalization. Finally, we construct a vector for banks that were restructured under PROES. Specifically, we construct Eventually Restructured, Restructured, and Time since Restructuring. Unlike for the previous three sectors, the timing of restructuring is hard to date; we chose the quarter, in which the debt relief contract between state and federal government was approved by the Federal Senate, as time of restructuring. Finally, we capture the remaining state banks that did not participate in the PROES, in the variable Non Participating State Banks.

We find a significant negative (positive) correlation of all Eventually variables with returns on assets and equity (overhead costs) (Table 4 Panel B), except for Eventually Federalized and Privatized. Privatized and Time since Privatization are significantly and positively correlated with ROA. All state and federal banks have a higher share of savings deposits relative to assets, which we explain by a higher retail orientation, while foreign banks have a lower share.

We control for the ownership structure of banks beyond the PROES. Specifically, we introduce dummy variables for the federally owned banks and for foreign-owned banks; privately owned domestic banks are the omitted category. We also include a number of variables to control for the size of the bank and its business orientation. Assets is the log of real assets measured at time t-1. Larger banks might have enjoyed scale or scope economies that had positive effects on their performance. Further, we include the ratio of fixed assets to 
total assets and the share of savings deposits over total assets to thus control for the business orientation of the bank. Finally, we control for year and season-specific effects. Specifically, we introduce dummy variables for the different years and for the four quarters.

Since we work with quarterly data and the effect of the transformation process might not be immediately effective, we drop the two quarters following immediately the transformation date. However, as noted below, we test for sensitivity of dropping these two periods.

Our sample contains data for both consolidated and unconsolidated banks.

Specifically, we use unconsolidated balance sheet and income statement information for bank groups, which include former state-owned banks, while we use consolidated information for other banks in our sample. To control for a potential selection bias, we introduce a dummy variable that takes the value one for banks for which we use unconsolidated information, i.e. which belonged to a bank group at some point during the sample period. We also introduce an interaction term of this dummy variable with the log of total assets. ${ }^{39}$

The quality of the data poses a challenge for estimation. Variation in the quality of reporting across banks and over time is exacerbated by the fact that our dataset was assembled from different databases of the Brazilian Central Bank. The mix of banks with consolidated and unconsolidated balance sheet information introduces another source of measurement error. All these factors bias our estimations against finding any significant relationship between the transformation process and bank performance. Following Cull, Matesova and Shirley (2002), we deal with this problem in two different ways. First, we restrict the sample

\footnotetext{
${ }^{39}$ We also considered using the total assets of the group instead of mixing consolidated and unconsolidated assets. However, this would introduce unnecessary noise since for privatized banks, total assets would jump in the period in which they are purchased by a large bank and thus bias the coefficient on Privatized and Privatized after Federalization towards zero.
} 
to values of the dependent variable between the $1^{\text {st }}$ and the $99^{\text {th }}$ percentiles to thus exclude outliers such as discussed above. Second, we use a robust estimation technique that uses all observations available, but assigns different weights to avoid the impact of outliers. Specifically, observations are weighted based on absolute residuals, with observations with large residuals being assigned smaller weights. Unlike in the case of the truncated sample, where we assign a zero weight a-priori to observations with extreme values and one to all others, the robust regressions assign these weights in an iterative process.

We use several additional tests. First, we test for differences across different state banks that underwent different treatments during PROES, including state banks that did not participate. This provides us with an additional test - beyond the estimations in section 3 - of whether a state government's decision for a specific option was influenced by its bank's performance. Second, we test whether the different policy options achieved its purpose, i.e. improved the negative performance that was the trigger for the PROES in the first place. Third, we compare the performance impact of the different options with each other.

\section{PROES and bank performance}

Tables 5 and 6 present our main results. Table 5 presents results without the Time since variables, while the regressions in Table 6 include them. We present both (i) regressions limiting our sample between the $1^{\text {st }}$ and the $99^{\text {th }}$ percentile and (ii) robust regressions. Finally, in the case of ROA and ROE, we present regressions with and without overhead costs/assets as explanatory variable, to evaluate whether transformation has had any effect on performance beyond efficiency improvements. 
The results in Panel A of Table 5 indicate that (i) all groups of state-owned banks were weaker than privately owned domestic banks (the omitted category) and (ii) PROES led to an improvement in performance. Eventually Federalized and Privatized, Eventually Federalized and Eventually Privatized enter significantly and negatively in the ROA and ROE regressions and significantly and positively in the overhead cost regressions. Eventually Restructured enters significantly and negatively in the ROE and ROA regressions, but insignificantly in the overhead cost regressions, which might indicate less need for operational restructuring than in other state banks. Non-participating state banks enters with the expected sign in all regressions, but not always significantly. In unreported tests, we also tested for differences between the different groups of state banks; while some differences are significant, there is no consistent pattern, except that non-participating banks performed in general better than state banks that did participate under PROES. While this seemingly confirms the results in Table 3 that the economic situation of these banks did not impact the political decision that state governments took on these banks, data quality and the omission of liquidated banks prevent any definitive conclusions. ${ }^{40}$ The regressions also indicate that federal banks have worse performance than privately owned domestic banks, while foreign-owned have lower overhead costs, but also lower ROA and ROE than privately owned domestic banks. Further, larger banks have lower overhead costs; banks with a higher share of fixed assets have lower returns on assets and equity, while banks with a larger share of savings deposits have higher overhead costs.

We find strong evidence that privatization by state governments and federalization has significant effects on performance, increasing ROA and ROE and decreasing overhead costs.

\footnotetext{
${ }^{40}$ Of course, there is the possibility that there is a correlation between under-reporting of losses and true financial situation of these banks, which could explain that we do not have any significant differences between state banks that went through different transformation options.
} 
In the case of privatization by the federal government, most of the improvement follows federalization; there is only limited evidence of a further increase in ROA and ROE (only in the robust regressions) and no evidence of further decreases in overhead costs after privatization. ${ }^{41}$ There is evidence of performance improvements through restructuring of state banks; however, this evidence is not robust across different estimation techniques, most likely caused by measurement error in the timing of the restructuring. Finally, we note that there is not much difference in coefficient size and significance in the ROE and ROA regressions that exclude and include overhead costs/assets, so that any performance improvements were beyond cost efficiency gains.

Did transformation close the initial gap to privately owned domestic banks? The tests in Panel B of Table 5 suggest differences in the extent to which the different options had success in making up for the initial underperformance of state banks. First, the federalization and subsequent privatization increased returns on assets and equity beyond that of privately owned domestic banks, but did not help reduce overhead costs from their initially high level. Second, in the case of state banks privatized by the states, privatization could not make up for the initially low ROE, but improved ROA and lowered overhead costs beyond the initially low level. Third, there is not consistent evidence on the success of federalization beyond the original underperformance; while most tests enter significantly, the signs differ across different estimation methods. Finally, the restructuring of state banks could not make up for the initial underperformance.

Restructuring state banks seemed to have been the least successful option, while we cannot find significant differences between the other alternatives. The tests in Panel B of Table 5 indicate that restructuring led to lower increases in ROA than privatization by the

\footnotetext{
${ }^{41}$ Note, however, that both dummy variables enter jointly significantly in all but one regression.
} 
federal or state government. Restructuring led to less reduction in overhead costs than in the case of federalization (with pending privatization) and privatization by the state.

The results in Panel A of Table 6 suggest continuous performance improvements in the cases of state banks that were federalized, federalized and privatized and privatized by the state, but not in the case of restructured banks. Time since Privatization after Federalization enters significantly and positively in the ROA and ROE regressions, but insignificantly in the overhead costs regressions; Time since Privatization and Time since Federalization enter significantly and positively (negatively) in the ROA (overhead costs) regressions. Time since Restructuring, on the other hand, does not enter significantly in any regression. In many regressions, the Time since variable “crowds out” the Action variable; Privatized after Federalized, Privatized and Federalized often enter insignificantly. This indicates that there was a slow continuing improvement in efficiency and performance rather than a one-time jump.

The results in Table 6 Panel B suggest that two years after the privatization or restructuring, only privatization by the federal government led to improvements in returns on assets and equity beyond the gap to privately owned domestic banks, while still not making up for the initially high overhead costs. Here we evaluate the effect of different PROES options two years after the action. As in Table 5B, we find that federalization and privatization increases returns on assets and equity beyond the initially low level. In the case of privatization by the state, we find an improvement beyond the initial gap to privately owned domestic banks only in the case of overhead costs, while there is no improvement in ROE beyond the initially low level. Unlike the regressions of Table 5, here we do not find any consistent evidence for the ROA regressions. In the case of federalization (with pending 
privatization), we cannot find any consistent evidence across the different estimation techniques. Restructuring, on the other hand, has not helped make up for initially low performance.

The tests in Panel B of Table 6 suggest that restructuring was the least successful PROES options. Restructured state banks show less improvement in ROA than other transformed state banks and less reduction in overhead costs than privatized and federalized banks. We also find evidence that privatization by the federal government led to greater improvement in ROA than privatization by the state government.

We assessed the robustness of our bank-level results along several dimensions. First, we re-ran the regressions in Tables 5 and 6 using clustered errors. ${ }^{42}$ While the coefficient estimates are the same as under OLS regressions presented in Tables 5 and 6, the regressions in Table 7 control for correlations between error terms for individual banks. While the significance of many coefficients decreases, our main findings are confirmed when we use clustered error terms.

We also tested the robustness of our results to the number of periods we drop after the PROES action. Specifically, we re-ran all regressions, dropping no period and one period after federalization, privatization or restructuring. Again, our main results are confirmed.

We also re-ran our regressions controlling for changes in ownership unrelated to PROES (mostly M\&A activity between private banks) and other jumps in the data that we cannot account for. Even after controlling for these potential sources of measurement error, our main findings are again confirmed.

\footnotetext{
${ }^{42}$ See Deaton (1997, pp. 73-78) for a detailed discussion of clustering. Also, see Huber (1967) and Rogers (1993).
} 
Finally, we assessed the absolute and relative success of the different PROES options at time periods other than two years after action. When we evaluate the success of the different options at three years after transformation, both relative to the initially low performance and efficiency and relative to each other, we confirm our main findings.

\section{Conclusions}

The transformation of state-owned banks in Brazil, to most observers, was part of a larger process of banking reform in the wake of the Real Plan, and indeed part of an even larger process of privatization. But it also had unique features that distinguish it. State banks, more than other government-owned firms, had long served as machines for patronage and political rents. They required repeated bailouts and had poor operating ratios and dismal efficiency. The central role of financial intermediation in economic development made the transformation of state banks especially important.

This paper evaluated the program of state bank transformation in the late 1990s, analyzing both the factors explaining the options that state governments chose for their banks, as well as the effects of the different transformation options on performance. We find that political economy theories can explain states' choices best. The stronger the dependence on budget transfers from the federal government, the more likely a state is to agree to liquidation or privatization directly by the federal government. States that had other patronage tools in the form of development agencies and whose banks were already under federal control were also more likely to agree to give up control over their bank. Interestingly, economic and social factors cannot explain the government choices made under PROES. 
We find a significant performance improvement for privatized and federalized banks, but not for restructured banks. Though we face measurement errors in the case of restructured banks, we interpret this as evidence in favor of states relinquishing ownership control over their banks. These conclusions are further supported by tests revealing that restructuring seemed to be the least successful transformation method, when compared with the other options, and when measured both over the sample period and at specific points after the transformation process took place. 


\section{References}

Amorim Neto, Octavio (2002): Presidential Cabinets, Electoral Cycles, and Coalition Discipline in Brazil, in: Scott Mogenstern et al (Eds.): Legislative Politics in Latin America (Cambridge, UK)

Baer, Werner and Nader Nazmi (2002): Privatization and Restructuring of Banks in Brazil, Quarterly Review of Economics and Finance 40, 3-24.

Barth, James R.; Caprio, Gerard Jr.; Levine, Ross (2004): Bank Supervision and Regulation: What Works Best?, Journal of Financial Intermediation 13, 205-48.

Baumohl Weintraub; Nakane, Marcio I. (2005): Bank Privatization and Productivity: Evidence for Brazil, Journal of Banking and Finance, forthcoming.

Beck, Thorsten; Cull, Robert; Jerome, Afeikhena T. (2005): Bank Privatization and Performance: Evidence from Nigeria, Journal of Banking and Finance, forthcoming.

Berger, Allen N.; Clarke, George; Cull, Robert; Klapper, Leora; Udell, Gregory F. (2005): Governance and the Efficiency of Commercial Banks: Evidence from the Argentine Banking System, Journal of Banking and Finance, forthcoming.

Bevilaqua, Afonso S. (1999): State-Government Bailouts in Brazil, Catholic University of Rio de Janeiro, mimeo.

Biais, Bruno; Perotti, Enrico (2002): Machiavellian Privatization, American Economic Review 92, 240-58.

Boehmer, Ekkehart; Nash, Robert; Netter, Jeffry M. (2005): Bank Privatization in Developing and Developed Countries: Cross-Sectional Evidence on the Impact of Economic and Political Factors, Journal of Banking and Finance, forthcoming.

Clarke, George; Cull, Robert (1999): Why Privatize? The Case of Argentina's Public Provincial Banks, World Development 27, 867- 888.

Clarke, George; Cull, Robert (2002): Political and Economic Determinants of the Likelihood of Privatizing Argentine Public Banks, Journal of Law and Economics 45, 165-197.

Cull, Robert; Matesova, Jana; Shirley, Mary (2002): Ownership and the Temptation to Loot: Evidence from Privatized Firms in the Czech Republic, Journal of Comparative Economics 30, 1-24.

Deaton, Angus. (1997): The Analysis of Household Surveys. Baltimore, Maryland: John Hopkins Academic Press.

Dinc, Serdar (2005): Politicians and Banks: Political Influence on Government-Owned Banks in Emerging Countries, Journal of Financial Economics, forthcoming.

Folha de São Paulo, several issues.

Franco, Gustavo H.B. (1995) O Plano Real e Outros Ensaios (Rio de Janeiro, 1995) (2000). The Real Plan and the Exchange Rate. (Essays in International Finance n. 217) (Princeton, 2000). 
Huber, Peter J. (1967). "The Behavior of Maximum-Likelihood Estimates under NonStandard Conditions." In Proceedings of the Fifth Berkeley Symposium in Mathematical Statistics and Probability, edited by Lucien M. Le Cam and J. Neyman, pp. 221-233. Berkeley, California: University of California Press.

La Porta, Rafael; Lopez-de-Silanes; Shleifer, Andrei (2002): Government Ownership of Commercial Banks, Journal of Finance 57, 265-301.

Lundberg, Eduardo (1999): Saneamento do Sistema Financeiro-A Experiência Brasileira dos Últimos 25 Anos.(mimeo, Banco Central do Brasil).

Maia, Geraldo (1998): Restructuring the Banking System - the Case of Brazil, in BIS Policy Papers no. 6-August 1999 (Basil, Bank for International Settlements).

McQuerry, Elizabeth (2001): Managed Care for Brazil’s Banks, Federal Reserve Bank of Atlanta Economic Review, Second Quarter, 27-44.

Mendonça de Barros, José, Gustavo Loyola, and Joel Bogdanski (1997): Restructuring of the Financial Sector, mimeo.

Ness, Walter L., Jr. (2000): Reducing Government Bank Presence in the Brazilian Financial System: Why and How, Quarterly Review of Economics and Finance 40, 71-84.

Nicolau, Jairo Marconi (20020): Dados Eleitorais do Brasil, 1982- 2002 (edição eletrônica), http://www.iuperj.br/deb/port/

Olley, G.; Pakes, A. (1996): The Dynamics of Productivity in the Telecommunications Equipment Industry, Econometrica 64, 1263-97.

Perotti, Enrico C. (1995): Credible Privatization, American Economic Review 85, 847-59.

Pinheiro, Armando Castelar; Cabral, Celia (1998): Credit Markets in Brazil: The Role of Judicial Enforcement and Other Institutions, Ensaios BNDES 9.

Rogers, William. H. (1993). “Regression Standard Errors in Clustered Samples.” Stata Technical Bulletin Reprints 3, 88-94.

Siqueira, Francisco José de (nd.): Instituições Financeiras: Regimes Especiais no Direito Brasileiro (mimeo, Banco Central do Brasil).

Sola, Lourdes; Garman, Christopher da Cunha Bueno; Marques, Moisés S. (2001): Central Banking Reform and Overcoming the Moral Hazard Problem: The Case of Brazil, Brazilian Journal of Political Economy 21, 40-64. 
Table 1: Ownership Structure of the Brazilian Banking System

\begin{tabular}{|l|c|c|c|c|c|c|}
\hline & 1994 & 1995 & 1996 & 1997 & 1998 & 1999 \\
\hline Private Banks & 41.21 & 39.16 & 39 & 36.76 & 35.29 & 33.11 \\
\hline Foreign Banks & 7.16 & 8.39 & 9.79 & 12.82 & 18.38 & 23.19 \\
\hline Public Banks & 51.43 & 52.21 & 50.91 & 50.05 & 45.83 & 43.04 \\
\hline
\end{tabular}

Source: Banco Central do Brasil. A bank is defined as private, foreign or public according to its majority shareholder. 
Table 2: Transformation and Status of State Banks

\begin{tabular}{|c|c|c|}
\hline STATE & INSTITUTION & STATUS \\
\hline ACRE & BANACRE & Liquidated (Remainder converted to Development Agency) \\
\hline ALAGOAS & PRODUBAN & Liquidated (Remainder converted to Development Agency) \\
\hline AMAPA & BANAP & Liquidated \\
\hline AMAZONAS & BEA & Federalized and Privatized (bought by BRADESCO) \\
\hline \multirow[t]{2}{*}{ BAHIA } & BANEB & Privatized (bought by BRADESCO) \\
\hline & DESENBANCO & Converted to Development Agency in 2001 \\
\hline CEARA & BEC & Federalized; Intended for privatization, not yet privatized \\
\hline DISTRITO FEDERAL & BRB & Opted out of PROES \\
\hline \multirow[t]{2}{*}{ ESPIRITO SANTO } & BANESTES & Restructured; State Gov't trying to privatize bank, but stalled in scandal \\
\hline & BANDES & Opted out of PROES \\
\hline GOIAS & BEG & Federalized and Privatized (bought by Itaú) \\
\hline MARANHAO & BEM & Federalized; Intended for privatization, not yet privatized \\
\hline MATO GROSSO & BEMAT & Liquidated, in process of conversion to Development Agency \\
\hline MATO GROSSO DO SUL & - & \\
\hline \multirow[t]{4}{*}{ MINAS GERAIS } & CREDIREAL & Privatized (bought by BRADESCO and BCN) \\
\hline & BDMG & Restructured; kept by State \\
\hline & BEMGE & Privatized (bought by Itaú) \\
\hline & MINASCAIXA & Liquidated (process began in 1991 for MINASCAIXA) \\
\hline PARA & BANPARA & Restructured; kept by State Gov’t (portion converted to Development Agency) \\
\hline PARAIBA & PARAIBAN & Opted out of PROES; auctioned by State Government to ABN Amro \\
\hline PARANA & BANESTADO & Privatized (bought by Itaú) \\
\hline PERNAMBUCO & BANDEPE & Privatized (bought by ABN) \\
\hline PIAUI & BEP & Federalized; Intended for privatization, not yet privatized \\
\hline RIO DE JANEIRO & BANERJ & Privatized (bought by Itaú) \\
\hline \multirow[t]{2}{*}{ RIO GRANDE DO NORTE } & BANDERN & Liquidated \\
\hline & BDRN & Liquidated \\
\hline \multirow[t]{2}{*}{ RIO GRANDE DO SUL } & BANRISUL & Restructured; kept by State Government \\
\hline & CEE-RS & Liquidated \\
\hline \multirow[t]{2}{*}{ RONDONIA } & BERON & Liquidated \\
\hline & RONDONPOUP & Liquidated \\
\hline RORAIMA & BANER & Liquidated \\
\hline \multirow[t]{2}{*}{ SANTA CATARINA } & BESC & Federalized; Intended for privatization, not yet privatized \\
\hline & BADESC & Converted to Development Agency \\
\hline \multirow[t]{2}{*}{ SAO PAULO } & BANESPA & Privatized (bought by Santander) \\
\hline & NOSSA CAIXA/NOSSO BANCO & Restructured; kept by State Government \\
\hline SERGIPE & BANESE & Restructured; kept by State Government \\
\hline TOCANTINS & - & \\
\hline
\end{tabular}

SOURCES: drawn principally from Folha de São Paulo, Estado de São Paulo, Jornal do Comércio, Correio Brasiliense. 
Table 3: Political Economy vs. Development: What Predicts State Bank Transformation?

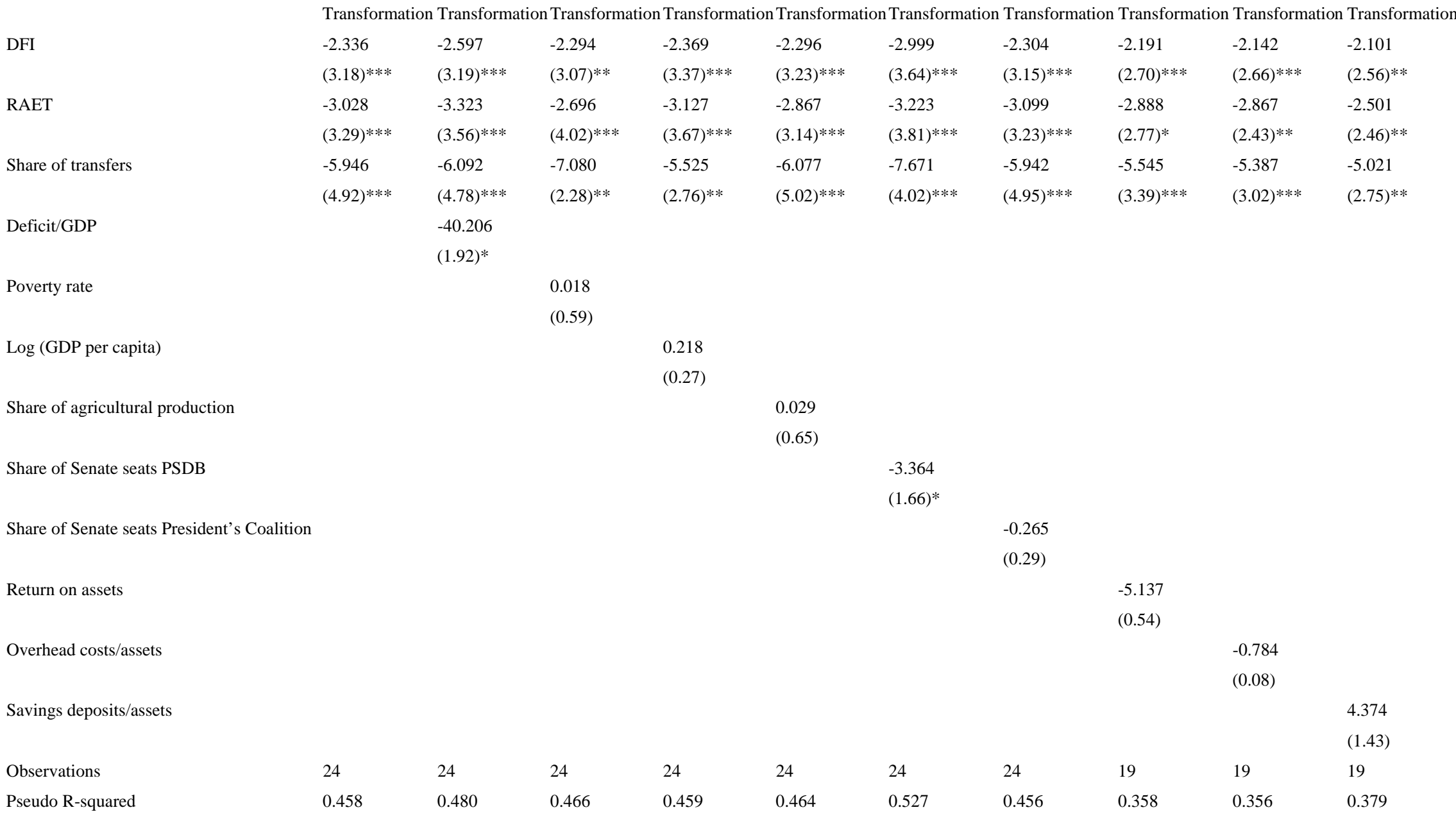

Regressions are run with ordered probit. T-statistics are reported in parentheses. *,**,*** indicate significance at the $10 \%, 5 \%$, and $1 \%$ level, respectively. 
Table 4: Descriptive statistics and correlations

Panel A: Descriptive statistics

\begin{tabular}{|c|c|c|c|c|c|c|c|c|}
\hline & $\begin{array}{l}\text { No } \\
\text { observations }\end{array}$ & Mean & Median & Std. Dev. & Min & Max & $1^{\text {st }}$ percentile & $99^{\text {th }}$ percentile \\
\hline Return on equity & 4809 & -0.13 & 0.03 & 2.30 & -61.12 & 6.74 & -2.58 & 0.27 \\
\hline Return on assets & 4810 & 0.00 & 0.00 & 0.04 & -1.24 & 0.37 & -0.13 & 0.07 \\
\hline Overhead costs/Assets & 4820 & 0.02 & 0.01 & 0.02 & 0 & 0.69 & 0.00 & 0.10 \\
\hline Assets (in millions) & 4820 & 5,387 & 642 & 17,495 & 2 & 213,412 & 7.73 & 108,428 \\
\hline Saving deposits/assets & 4820 & 0.03 & 0.00 & 0.07 & 0 & 0.48 & 0.00 & 0.32 \\
\hline Fixed assets/assets & 4820 & 0.08 & 0.04 & 0.11 & 0 & 0.98 & 0.00 & 0.63 \\
\hline Eventually Federalized and Privatized & 4820 & 0.02 & 0 & 0.13 & 0 & 1 & 0 & 1 \\
\hline Federalized before Privatization & 4820 & 0.01 & 0 & 0.11 & 0 & 1 & 0 & 1 \\
\hline Privatized after federalization & 4820 & 0.00 & 0 & 0.06 & 0 & 1 & 0 & 0 \\
\hline Time since privatization after federalization & 4820 & 0.02 & 0 & 0.38 & 0 & 10 & 0 & 0 \\
\hline Eventually Privatized & 4820 & 0.04 & 0 & 0.20 & 0 & 1 & 0 & 1 \\
\hline Privatized & 4820 & 0.02 & 0 & 0.14 & 0 & 1 & 0 & 1 \\
\hline Time since privatization & 4820 & 0.21 & 0 & 1.71 & 0 & 23 & 0 & 10 \\
\hline Eventually Federalized & 4820 & 0.02 & 0 & 0.15 & 0 & 1 & 0 & 1 \\
\hline Federalized & 4820 & 0.01 & 0 & 0.10 & 0 & 1 & 0 & 0 \\
\hline Time since federalization & 4820 & 0.07 & 0 & 0.82 & 0 & 16 & 0 & 0 \\
\hline Eventually Restructured & 4820 & 0.03 & 0 & 0.17 & 0 & 1 & 0 & 1 \\
\hline Restructured & 4820 & 0.01 & 0 & 0.12 & 0 & 1 & 0 & 1 \\
\hline Time since restructuring & 4820 & 0.15 & 0 & 1.41 & 0 & 21 & 0 & 7 \\
\hline Federal bank & 4820 & 0.03 & 0 & 0.18 & 0 & 1 & 0 & 1 \\
\hline Foreign bank & 4820 & 0.34 & 0 & 0.47 & 0 & 1 & 0 & 1 \\
\hline Non participating state bank & 4820 & 0.01 & 0 & 0.08 & 0 & 1 & 0 & 0 \\
\hline
\end{tabular}




\section{Panel B: Correlations}

Return on assets

Overhead costs/assets

Assets

Savings deposits/assets

Fixed assets/assets

Eventually Federalized and Privatized

Federalized before Privatization

Privatized after federalization

Time since privatization after federalization

Eventually Privatized

Privatized

Time since privatization

Eventually Federalized

Federalized

Time since federalization

Eventually Restructured

Restructured

Time since restructuring

Federal bank

Foreign bank

Non participating state bank

\begin{tabular}{|c|c|c|c|c|c|}
\hline $\begin{array}{l}\text { Return on } \\
\text { equity }\end{array}$ & $\begin{array}{l}\text { Return on } \\
\text { assets }\end{array}$ & $\begin{array}{l}\text { Overhead } \\
\text { costs/assets }\end{array}$ & Assets & $\begin{array}{l}\text { Savings } \\
\text { deposits/assets }\end{array}$ & $\begin{array}{l}\text { Fixed } \\
\text { assets/assets }\end{array}$ \\
\hline $0.59 * *$ & 1 & & & & \\
\hline$-0.31^{* * *}$ & $-0.24 * *$ & 1 & & & \\
\hline 0.02 & 0.00 & $-0.10^{*}$ & & & \\
\hline$-0.11^{* * *}$ & $-0.09 * * *$ & $0.13^{* * *}$ & $0.35^{* * *}$ & & \\
\hline$-0.04 * * *$ & $-0.08 * * *$ & $0.09 * *$ & -0.02 & 0.00 & \\
\hline 0.00 & 0.00 & $0.06 * * *$ & $0.07 * * *$ & $0.12 * * *$ & $-0.04 * * *$ \\
\hline 0.01 & 0.01 & 0.01 & $0.1^{* * *}$ & $0.07^{* * *}$ & $-0.04 * *$ \\
\hline 0.01 & 0.02 & 0.00 & $0.03^{*}$ & $0.04 * * *$ & -0.02 \\
\hline 0.01 & 0.02 & 0.00 & $0.03^{* *}$ & $0.04^{* * *}$ & -0.02 \\
\hline$-0.08 * * *$ & $-0.04 * * *$ & $0.1^{* * *}$ & -0.02 & $0.30 * *$ & -0.01 \\
\hline 0.00 & $0.03 * *$ & -0.02 & -0.02 & $0.22 * *$ & 0.02 \\
\hline 0.01 & $0.03 * *$ & $-0.04 *$ & -0.02 & $0.18^{* * *}$ & 0.02 \\
\hline$-0.08 * * *$ & $-0.07 * * *$ & $0.15^{* *}$ & $-0.04 * * *$ & $0.15^{* *}$ & $-0.04 * *$ \\
\hline 0.00 & -0.02 & $0.04 *$ & $-0.03^{*}$ & $0.14^{* * *}$ & $-0.04 * * *$ \\
\hline 0.00 & -0.02 & $0.04 * * *$ & -0.02 & $0.15^{* * *}$ & $-0.04 * * *$ \\
\hline$-0.06 * * *$ & $-0.05 * * *$ & $0.04 * * *$ & 0.00 & $0.43^{* *}$ & $-0.04 * * *$ \\
\hline 0.01 & 0.00 & 0.01 & 0.00 & $0.29 * * *$ & $-0.04 * * *$ \\
\hline 0.01 & 0.00 & 0.01 & 0.00 & $0.25^{* * *}$ & $-0.04 * * *$ \\
\hline 0.01 & -0.01 & -0.02 & $0.61 * * *$ & $0.18^{* * *}$ & $-0.03 * *$ \\
\hline $0.02 *$ & -0.03 & $-0.20^{*}$ & $-0.06 * * *$ & $-0.18 * * *$ & $-0.16 * * *$ \\
\hline 0.00 & 0.00 & $0.07 * * *$ & -0.02 & $0.17 * * *$ & 0.01 \\
\hline
\end{tabular}


Table 5: State bank transformation and performance

\begin{tabular}{|c|c|c|c|c|c|c|c|c|c|c|}
\hline \multirow{2}{*}{ Panel A: } & \multicolumn{5}{|c|}{ White } & \multicolumn{5}{|c|}{ Robust } \\
\hline & $\begin{array}{l}\text { Return on } \\
\text { equity }\end{array}$ & $\begin{array}{l}\text { Return on } \\
\text { assets }\end{array}$ & $\begin{array}{l}\text { Overhead } \\
\text { costs/assets }\end{array}$ & $\begin{array}{l}\text { Return on } \\
\text { equity }\end{array}$ & $\begin{array}{l}\text { Return on } \\
\text { assets }\end{array}$ & $\begin{array}{l}\text { Return on } \\
\text { equity }\end{array}$ & $\begin{array}{l}\text { Return on } \\
\text { assets }\end{array}$ & $\begin{array}{l}\text { Overhead } \\
\text { costs/assets }\end{array}$ & $\begin{array}{l}\text { Return on } \\
\text { equity }\end{array}$ & $\begin{array}{l}\text { Return on } \\
\text { assets }\end{array}$ \\
\hline Log of Assets & 0.0034 & -0.0008 & -0.0047 & 0.0022 & -0.0012 & 0.0030 & -0.0006 & -0.0021 & 0.0025 & -0.0006 \\
\hline \multirow[t]{2}{*}{ Eventually Federalized and Privatized } & -0.1575 & -0.0151 & 0.0159 & -0.1533 & -0.0136 & -0.0320 & -0.0089 & 0.0147 & -0.0313 & -0.0090 \\
\hline & $(2.55)^{* *}$ & $(3.56)^{* * *}$ & $(3.29)^{* * *}$ & $(2.49)^{* *}$ & $(3.20)^{* * *}$ & $(3.51)^{* * *}$ & $(5.03)^{* * *}$ & $(6.86)^{* * *}$ & $(3.43)^{* * *}$ & $(5.10)^{* * *}$ \\
\hline Federalized before Privatization & 0.1462 & 0.0124 & -0.0053 & 0.1448 & 0.0117 & 0.0454 & 0.0087 & -0.0068 & 0.0456 & 0.0088 \\
\hline \multirow[t]{2}{*}{ Privatized after Federalization } & 0.0375 & 0.0079 & -0.0040 & 0.0364 & 0.0075 & 0.0521 & 0.0109 & -0.0003 & 0.0510 & 0.0110 \\
\hline & $(1.04)$ & (1.38) & $(1.02)$ & $(1.01)$ & (1.33) & $(3.98)^{* * *}$ & $(4.33)^{* * *}$ & $(0.10)$ & $(3.91)^{* * *}$ & $(4.35)^{* * *}$ \\
\hline \multirow[t]{2}{*}{ Eventually Privatized } & -0.2301 & -0.0159 & 0.0139 & -0.2264 & -0.0148 & -0.0302 & -0.0070 & 0.0083 & -0.0281 & -0.0071 \\
\hline & $(4.62)^{* * *}$ & $(5.93)^{* * *}$ & $(5.47)^{* * *}$ & $(4.54)^{* * *}$ & $(5.69)^{* * *}$ & $(5.42)^{* * *}$ & $(6.54)^{* * *}$ & $(6.31)^{* * *}$ & $(5.03)^{* * *}$ & $(6.57)^{* * *}$ \\
\hline \multirow[t]{2}{*}{ Privatized } & 0.1913 & 0.0174 & -0.0178 & 0.1866 & 0.0160 & 0.0194 & 0.0110 & -0.0119 & 0.0166 & 0.0112 \\
\hline & $(3.37)^{* * *}$ & $(5.34)^{* * *}$ & $(5.68)^{* * *}$ & $(3.27)^{* * *}$ & $(5.06)^{* * *}$ & $(2.89)^{* * *}$ & $(8.53)^{* * *}$ & $(7.55)^{* * *}$ & $(2.46)^{* *}$ & $(8.61)^{* * *}$ \\
\hline Eventually Federalized & -0.1659 & -0.0175 & 0.0186 & -0.1609 & -0.0158 & -0.0258 & -0.0053 & 0.0227 & -0.0238 & -0.0055 \\
\hline \multirow[t]{2}{*}{ Federalized } & 0.1639 & 0.0164 & -0.0198 & 0.1586 & 0.0146 & 0.0275 & 0.0039 & -0.0182 & 0.0253 & 0.0041 \\
\hline & $(2.57)^{* *}$ & $(4.37)^{* * *}$ & $(6.14)^{* * *}$ & $(2.52)^{* *}$ & $(4.00)^{* * *}$ & $(3.11)^{* * *}$ & $(2.29)^{* *}$ & $(8.74)^{* * *}$ & $(2.86)^{* * *}$ & $(2.39)^{* *}$ \\
\hline \multirow[t]{2}{*}{ Eventually Restructured } & -0.1416 & -0.0071 & 0.0001 & -0.1415 & -0.0071 & -0.0224 & -0.0034 & 0.0008 & -0.0229 & -0.0033 \\
\hline & $(2.26)^{* *}$ & $(2.58)^{* * *}$ & $(0.07)$ & $(2.26)^{* *}$ & $(2.59)^{* * *}$ & $(3.56)^{* * *}$ & $(2.78)^{* * *}$ & $(0.54)$ & $(3.65)^{* * *}$ & $(2.73)^{* * *}$ \\
\hline \multirow[t]{2}{*}{ Restructured } & 0.1309 & 0.0046 & -0.0045 & 0.1297 & 0.0042 & 0.0214 & 0.0004 & -0.0022 & 0.0214 & 0.0004 \\
\hline & $(2.24)^{* *}$ & $(1.87)^{*}$ & $(2.32)^{* *}$ & $(2.23)^{* *}$ & $(1.74)^{*}$ & $(2.76)^{* * *}$ & $(0.29)$ & $(1.19)$ & $(2.77)^{* * *}$ & $(0.29)$ \\
\hline \multirow[t]{2}{*}{ Federal bank } & -0.0917 & -0.0046 & 0.0095 & -0.0892 & -0.0039 & -0.0274 & -0.0020 & 0.0069 & -0.0264 & -0.0020 \\
\hline & $(4.05)^{* * *}$ & $(4.45)^{* * *}$ & $(8.50)^{* * *}$ & $(3.90)^{* * *}$ & $(3.74)^{* * *}$ & $(6.48)^{* * *}$ & $(2.42)^{* *}$ & $(6.93)^{* * *}$ & $(6.25)^{* * *}$ & $(2.51)^{* *}$ \\
\hline \multirow[t]{2}{*}{ Foreign-owned bank } & -0.0419 & -0.0047 & -0.0025 & -0.0425 & -0.0049 & -0.0119 & -0.0025 & -0.0016 & -0.0123 & -0.0025 \\
\hline & $(6.32)^{* * *}$ & $(7.42)^{* * *}$ & $(3.97)^{* * *}$ & $(6.44)^{* * *}$ & $(7.75)^{* * *}$ & $(7.68)^{* * *}$ & $(8.46)^{* * *}$ & $(4.49)^{* * *}$ & $(7.95)^{* * *}$ & $(8.34)^{* * *}$ \\
\hline \multirow[t]{2}{*}{ Not participating state bank } & -0.0150 & -0.0028 & 0.0156 & -0.0109 & -0.0015 & -0.0286 & -0.0044 & 0.0192 & -0.0267 & -0.0046 \\
\hline & $(0.85)$ & (1.59) & $(12.91)^{* * *}$ & $(0.61)$ & $(0.88)$ & $(3.30)^{* * *}$ & $(2.65)^{* * *}$ & $(9.41)^{* * *}$ & $(3.08)^{* * *}$ & $(2.77)^{* * *}$ \\
\hline \multirow[t]{2}{*}{ Saving deposits/assets } & -0.1467 & -0.0146 & 0.0778 & -0.1260 & -0.0085 & -0.0418 & -0.0045 & 0.0727 & -0.0321 & -0.0054 \\
\hline & $(1.86)^{*}$ & $(3.21)^{* * *}$ & $(19.65)^{* * *}$ & (1.55) & $(1.89)^{*}$ & $(3.06)^{* * *}$ & $(1.71)^{*}$ & $(22.67)^{* * *}$ & $(2.32)^{* *}$ & $(2.01)^{* *}$ \\
\hline
\end{tabular}




\begin{tabular}{|c|c|c|c|c|c|c|c|c|c|c|}
\hline & \multicolumn{5}{|c|}{ White } & \multicolumn{5}{|c|}{ Robust } \\
\hline & $\begin{array}{l}\text { Return on } \\
\text { equity }\end{array}$ & $\begin{array}{l}\text { Return on } \\
\text { assets }\end{array}$ & $\begin{array}{l}\text { Overhead } \\
\text { costs/assets }\end{array}$ & $\begin{array}{l}\text { Return on } \\
\text { equity }\end{array}$ & $\begin{array}{l}\text { Return on } \\
\text { assets }\end{array}$ & $\begin{array}{l}\begin{array}{l}\text { Return on } \\
\text { equity }\end{array} \\
\end{array}$ & $\begin{array}{l}\text { Return on } \\
\text { assets }\end{array}$ & $\begin{array}{l}\text { Overhead } \\
\text { costs/assets }\end{array}$ & $\begin{array}{l}\text { Return on } \\
\text { equity }\end{array}$ & $\begin{array}{l}\text { Return on } \\
\text { assets }\end{array}$ \\
\hline Fixed assets/assets & $\begin{array}{l}-0.1461 \\
(4.92)^{* * *}\end{array}$ & $\begin{array}{l}-0.0185 \\
(3.86)^{* * *}\end{array}$ & $\begin{array}{l}-0.0023 \\
(0.73)\end{array}$ & $\begin{array}{l}-0.1468 \\
(4.96)^{* * *}\end{array}$ & $\begin{array}{l}-0.0186 \\
(3.95)^{* * *}\end{array}$ & $\begin{array}{l}-0.0359 \\
(5.62)^{* * *}\end{array}$ & $\begin{array}{l}-0.0027 \\
(2.21)^{* *}\end{array}$ & $\begin{array}{l}-0.0011 \\
(0.76)\end{array}$ & $\begin{array}{l}-0.0360 \\
(5.64)^{* * *}\end{array}$ & $\begin{array}{l}-0.0028 \\
(2.27)^{* *}\end{array}$ \\
\hline Overhead costs/assets & & & & $\begin{array}{l}-0.2655 \\
(1.37)\end{array}$ & $\begin{array}{l}-0.0786 \\
(3.81)^{* * *}\end{array}$ & & & & $\begin{array}{l}-0.1233 \\
(3.62)^{* * *}\end{array}$ & $\begin{array}{l}0.0122 \\
(2.06)^{* *}\end{array}$ \\
\hline Constant & $\begin{array}{l}0.0262 \\
(0.34)\end{array}$ & $\begin{array}{l}0.0223 \\
(2.30)^{* *}\end{array}$ & $\begin{array}{l}0.0938 \\
(6.19)^{* * *}\end{array}$ & $\begin{array}{l}0.0511 \\
(0.65)\end{array}$ & $\begin{array}{l}0.0299 \\
(3.26)^{* * *}\end{array}$ & $\begin{array}{l}-0.0091 \\
(0.47)\end{array}$ & $\begin{array}{l}0.0174 \\
(4.53)^{* * *}\end{array}$ & $\begin{array}{l}0.0474 \\
(10.30)^{* * *}\end{array}$ & $\begin{array}{l}0.0009 \\
(0.04)\end{array}$ & $\begin{array}{l}0.0164 \\
(4.22)^{* * *}\end{array}$ \\
\hline Observations & 4715 & 4720 & 4715 & 4715 & 4720 & 4809 & 4810 & 4820 & 4808 & 4810 \\
\hline R-squared & 0.08 & 0.06 & 0.25 & 0.08 & 0.07 & 0.08 & 0.08 & 0.37 & 0.08 & 0.08 \\
\hline Panel B: & & & & & & & & & & \\
\hline Bridging the gap? & & & & & & & & & & \\
\hline Federalized and Privatized & $0.0262^{* * *}$ & $0.0052^{* * *}$ & $0.0066^{* *}$ & $0.0279 * * *$ & $0.0056^{* * *}$ & $0.0655^{* * *}$ & $0.0107 * * *$ & $0.0076^{* * *}$ & $0.0653^{* * *}$ & $0.0108^{* * *}$ \\
\hline Privatized & $-0.0388 * * *$ & $0.0015^{* * *}$ & $-0.0039 * * *$ & $-0.0398 * * *$ & $0.0012^{* * *}$ & $-0.0108 * * *$ & $0.004^{* * *}$ & $-0.0036^{* * *}$ & $-0.0115^{* * *}$ & $0.0041^{* * *}$ \\
\hline Federalized & $-0.002 * * *$ & $-0.0011^{* * *}$ & $-0.0012 * * *$ & $-0.0023 * * *$ & $-0.0012 * * *$ & $0.0017 * * *$ & $-0.0014 * * *$ & $0.0045^{* * *}$ & $0.0015^{* * *}$ & $-0.0014 * * *$ \\
\hline Compare options & & & & & & & & & & \\
\hline Federalized w/ and w/o privatization & -0.0177 & -0.004 & $0.0145^{* *}$ & -0.0138 & -0.0029 & 0.0179 & $0.0048^{*}$ & $0.0114^{* * *}$ & 0.0203 & $0.0047^{*}$ \\
\hline Privatized by federal vs. state govt & -0.0076 & 0.0029 & 0.0085 & -0.0054 & 0.0032 & $0.0781^{* * *}$ & $0.0086^{* * *}$ & 0.0048 & $0.08^{* * *}$ & $0.0086^{* * *}$ \\
\hline Federalized and privatized vs. restructured & d 0.0528 & $0.0157^{* *}$ & -0.0048 & 0.0515 & $0.015^{* *}$ & $0.0761^{* * *}$ & $0.0192^{* * *}$ & -0.0049 & $0.0752^{* * *}$ & $0.0194 * * *$ \\
\hline Privatized vs. restructured & 0.0604 & $0.0128 * * *$ & $-0.0133^{* * *}$ & 0.0569 & $0.0118^{* * *}$ & -0.002 & $0.0106^{* * *}$ & $-0.0097 * * *$ & -0.0048 & $0.0108^{* * *}$ \\
\hline Federalized vs. privatized & -0.0274 & -0.001 & -0.002 & -0.028 & -0.0014 & 0.0081 & $-0.0071^{* * *}$ & $-0.0063^{* *}$ & 0.0087 & $-0.0071^{* * *}$ \\
\hline Federalized vs. restructured & 0.033 & $0.0118^{* * * *}$ & $-0.0153^{* * *}$ & 0.0289 & $0.0104^{* *}$ & 0.0061 & 0.0035 & $-0.016^{* * *}$ & 0.0039 & 0.0037 \\
\hline
\end{tabular}

T-statistics are reported in parentheses. *,**,*** indicate significance at the $10 \%, 5 \%$, and $1 \%$ level, respectively. The tests in the panel Bridging the gap test for the difference between (i) Eventually Federalized and Privatized and Federalized before Privatization plus Privatized after Federalization, (ii) Eventually Privatized and Privatized, (iii) Eventually Federalized and Federalized and (iv) Eventually Restructured and Restructured. The tests in the panel Compare options test for the difference between (i) Federalized before Privatization and Federalized, (ii) Federalized before Privatization plus Privatized after Federalization and Privatized, (iii) Federalized before Privatization plus Privatized after Federalization and Restructured, (iv) Privatized and Restructured, (v) Federalized and Privatized, and (vi) Federalized and Restructured. 
Table 6: State bank transformation and performance: effects over time

\begin{tabular}{|c|c|c|c|c|c|c|c|c|c|c|}
\hline \multirow{2}{*}{ Panel A: } & \multicolumn{4}{|c|}{ White } & \multicolumn{6}{|c|}{ Robust } \\
\hline & $\begin{array}{l}\text { Return on } \\
\text { equity }\end{array}$ & $\begin{array}{l}\text { Return on } \\
\text { assets }\end{array}$ & $\begin{array}{l}\text { Overhead } \\
\text { costs/assets }\end{array}$ & $\begin{array}{l}\text { Return on } \\
\text { equity }\end{array}$ & $\begin{array}{l}\text { Return on } \\
\text { assets }\end{array}$ & $\begin{array}{l}\text { Return on } \\
\text { equity }\end{array}$ & $\begin{array}{l}\text { Return on } \\
\text { assets }\end{array}$ & $\begin{array}{l}\text { Overhead } \\
\text { costs/assets }\end{array}$ & $\begin{array}{l}\text { Return on } \\
\text { equity }\end{array}$ & $\begin{array}{l}\text { Return on } \\
\text { assets }\end{array}$ \\
\hline \multirow[t]{2}{*}{ Log of Assets } & 0.0032 & -0.0009 & -0.0047 & 0.0020 & -0.0012 & 0.0031 & -0.0007 & -0.0022 & 0.0027 & -0.0006 \\
\hline & $(0.71)$ & $(1.59)$ & $(5.56)^{* * *}$ & $(0.43)$ & $(2.42)^{* *}$ & $(2.80)^{* * *}$ & $(3.26)^{* * *}$ & $(8.30)^{* * *}$ & $(2.37)^{* *}$ & $(2.94)^{* * *}$ \\
\hline \multirow[t]{2}{*}{ Eventually Federalized and Privatized } & -0.1581 & -0.0152 & 0.0159 & -0.1540 & -0.0138 & -0.0314 & -0.0092 & 0.0147 & -0.0307 & -0.0094 \\
\hline & $(2.56)^{* *}$ & $(3.59)^{* * *}$ & $(3.28)^{* * *}$ & $(2.50)^{* *}$ & $(3.23)^{* * *}$ & $(3.46)^{* * *}$ & $(5.28)^{* * *}$ & $(6.87)^{* * *}$ & $(3.38)^{* * *}$ & $(5.36)^{* * *}$ \\
\hline \multirow[t]{2}{*}{ Federalized before Privatization } & 0.1465 & 0.0124 & -0.0051 & 0.1452 & 0.0118 & 0.0446 & 0.0090 & -0.0067 & 0.0448 & 0.0091 \\
\hline & $(2.31)^{* *}$ & $(2.66)^{* * *}$ & $(0.96)$ & $(2.30)^{* *}$ & $(2.53)^{* *}$ & $(3.85)^{* * *}$ & $(4.07)^{* * *}$ & $(2.44)^{* *}$ & $(3.87)^{* * *}$ & $(4.10)^{* * *}$ \\
\hline \multirow[t]{2}{*}{ Privatized after Federalization } & -0.1356 & -0.0227 & -0.0038 & -0.1366 & -0.0231 & -0.0698 & -0.0129 & 0.0050 & -0.0703 & -0.0129 \\
\hline & $(1.56)$ & $(1.91)^{*}$ & $(0.37)$ & $(1.58)$ & $(1.99)^{* *}$ & $(2.21)^{* *}$ & $(2.14)^{* *}$ & $(0.68)$ & $(2.23)^{* *}$ & $(2.14)^{* *}$ \\
\hline \multirow{2}{*}{ Time since Privatization after Federalization } & 0.0296 & 0.0052 & -0.0001 & 0.0296 & 0.0052 & 0.0210 & 0.0044 & -0.0009 & 0.0210 & 0.0044 \\
\hline & $(2.71)^{* * *}$ & $(3.17)^{* * *}$ & $(0.08)$ & $(2.72)^{* * *}$ & $(3.22)^{* * *}$ & $(4.31)^{* * *}$ & $(4.69)^{* * *}$ & $(0.77)$ & $(4.32)^{* * *}$ & $(4.70)^{* * *}$ \\
\hline \multirow[t]{2}{*}{ Eventually Privatized } & -0.2304 & -0.0160 & 0.0139 & -0.2268 & -0.0149 & -0.0299 & -0.0072 & 0.0083 & -0.0280 & -0.0073 \\
\hline & $(4.63)^{* * *}$ & $(5.95)^{* * *}$ & $(5.47)^{* * *}$ & $(4.55)^{* * *}$ & $(5.73)^{* * *}$ & $(5.39)^{* * *}$ & $(6.72)^{* * *}$ & $(6.36)^{* * *}$ & $(5.00)^{* * *}$ & $(6.78)^{* * *}$ \\
\hline \multirow[t]{2}{*}{ Privatized } & 0.1704 & 0.0082 & -0.0052 & 0.1691 & 0.0079 & 0.0191 & 0.0012 & -0.0004 & 0.0177 & 0.0013 \\
\hline & $(2.67)^{* * *}$ & $(1.54)$ & $(1.34)$ & $(2.65)^{* * *}$ & $(1.53)$ & $(1.79)^{*}$ & $(0.60)$ & $(0.17)$ & $(1.65)^{*}$ & $(0.63)$ \\
\hline \multirow[t]{2}{*}{ Time since Privatization } & 0.0020 & 0.0009 & -0.0012 & 0.0017 & 0.0008 & 0.0000 & 0.0009 & -0.0010 & -0.0001 & 0.0009 \\
\hline & $(1.16)$ & $(2.70)^{* * *}$ & $(6.92)^{* * *}$ & $(0.98)$ & $(2.44)^{* *}$ & $(0.04)$ & $(6.03)^{* * *}$ & $(5.29)^{* * *}$ & $(0.09)$ & $(6.13)^{* * *}$ \\
\hline \multirow[t]{2}{*}{ Eventually Federalized } & -0.1660 & -0.0175 & 0.0186 & -0.1612 & -0.0159 & -0.0257 & -0.0054 & 0.0227 & -0.0238 & -0.0056 \\
\hline & $(2.61)^{* * *}$ & $(5.19)^{* * *}$ & $(8.70)^{* * *}$ & $(2.57)^{* *}$ & $(4.78)^{* * *}$ & $(4.60)^{* * *}$ & $(5.00)^{* * *}$ & $(17.29)^{* * *}$ & $(4.22)^{* * *}$ & $(5.19)^{* * *}$ \\
\hline \multirow{2}{*}{ Federalized } & 0.1273 & 0.0086 & -0.0077 & 0.1253 & 0.0077 & 0.0007 & -0.0014 & -0.0073 & 0.0003 & -0.0013 \\
\hline & $(1.92)^{*}$ & $(2.16)^{* *}$ & $(1.48)$ & $(1.91)^{*}$ & $(2.00)^{* *}$ & $(0.04)$ & $(0.43)$ & $(1.80)^{*}$ & $(0.02)$ & $(0.41)$ \\
\hline \multirow[t]{2}{*}{ Time since Federalization } & 0.0048 & 0.0010 & -0.0016 & 0.0044 & 0.0009 & 0.0036 & 0.0007 & -0.0015 & 0.0034 & 0.0007 \\
\hline & $(1.83)^{*}$ & $(3.67)^{* * *}$ & $(3.03)^{* * *}$ & $(1.70)^{*}$ & $(3.47)^{* * *}$ & $(1.89)^{*}$ & $(1.97)^{* *}$ & $(3.46)^{* * *}$ & $(1.77)^{*}$ & $(2.04)^{* *}$ \\
\hline \multirow[t]{2}{*}{ Eventually Restructured } & -0.1414 & -0.0071 & -0.0000 & -0.1415 & -0.0071 & -0.0216 & -0.0035 & 0.0007 & -0.0221 & -0.0034 \\
\hline & $(2.25)^{* *}$ & $(2.56)^{* *}$ & $(0.03)$ & $(2.26)^{* *}$ & $(2.58)^{* * *}$ & $(3.45)^{* * *}$ & $(2.92)^{* * *}$ & $(0.51)$ & $(3.54)^{* * *}$ & $(2.87)^{* * *}$ \\
\hline \multirow[t]{2}{*}{ Restructured } & 0.0886 & 0.0037 & -0.0048 & 0.0874 & 0.0033 & 0.0062 & -0.0004 & -0.0016 & 0.0065 & -0.0004 \\
\hline & $(1.21)$ & $(1.41)$ & $(1.86)^{*}$ & $(1.20)$ & $(1.28)$ & $(0.46)$ & $(0.16)$ & $(0.51)$ & $(0.48)$ & $(0.16)$ \\
\hline \multirow[t]{2}{*}{ Time since Restructuring } & 0.0041 & 0.0001 & 0.0000 & 0.0041 & 0.0001 & 0.0014 & 0.0001 & -0.0001 & 0.0014 & 0.0001 \\
\hline & $(1.19)$ & $(0.81)$ & $(0.10)$ & $(1.19)$ & $(0.81)$ & $(1.35)$ & $(0.44)$ & $(0.25)$ & (1.33) & $(0.44)$ \\
\hline \multirow[t]{2}{*}{ Federal bank } & -0.0917 & -0.0046 & 0.0094 & -0.0892 & -0.0039 & -0.0272 & -0.0020 & 0.0069 & -0.0263 & -0.0021 \\
\hline & $(4.04)^{* * *}$ & $(4.44)^{* * *}$ & $(8.47)^{* * *}$ & $(3.90)^{* * *}$ & $(3.75)^{* * *}$ & $(6.46)^{* * *}$ & $(2.48)^{* *}$ & $(6.93)^{* * *}$ & $(6.24)^{* * *}$ & $(2.60)^{* * *}$ \\
\hline \multirow[t]{2}{*}{ Foreign-owned bank } & -0.0418 & -0.0047 & -0.0025 & -0.0425 & -0.0049 & -0.0119 & -0.0025 & -0.0016 & -0.0123 & -0.0025 \\
\hline & $(6.32)^{* * *}$ & $(7.41)^{* * *}$ & $(3.96)^{* * *}$ & $(6.43)^{* * *}$ & $(7.74)^{* * *}$ & $(7.73)^{* * *}$ & $(8.59)^{* * *}$ & $(4.46)^{* * *}$ & $(7.98)^{* * *}$ & $(8.44)^{* * *}$ \\
\hline
\end{tabular}




\begin{tabular}{|c|c|c|c|c|c|c|c|c|c|c|}
\hline & \multicolumn{5}{|c|}{ White } & \multicolumn{5}{|c|}{ Robust } \\
\hline & $\begin{array}{c}\text { Return on } \\
\text { equity }\end{array}$ & $\begin{array}{c}\text { Return on } \\
\text { assets }\end{array}$ & $\begin{array}{c}\text { Overhead } \\
\text { costs/assets }\end{array}$ & $\begin{array}{c}\text { Return on } \\
\text { equity }\end{array}$ & $\begin{array}{c}\text { Return on } \\
\text { assets }\end{array}$ & $\begin{array}{c}\text { Return on } \\
\text { equity }\end{array}$ & $\begin{array}{c}\text { Return on } \\
\text { assets }\end{array}$ & $\begin{array}{c}\text { Overhead } \\
\text { costs/assets }\end{array}$ & $\begin{array}{c}\text { Return on } \\
\text { equity }\end{array}$ & $\begin{array}{c}\text { Return on } \\
\text { assets }\end{array}$ \\
\hline \multirow[t]{2}{*}{ Not participating state bank } & -0.0148 & -0.0027 & 0.0154 & -0.0108 & -0.0015 & -0.0279 & -0.0045 & 0.0191 & -0.0260 & -0.0048 \\
\hline & $(0.83)$ & $(1.55)$ & $(13.02)^{* * *}$ & $(0.60)$ & $(0.87)$ & $(3.23)^{* * *}$ & $(2.73)^{* * *}$ & $(9.39)^{* * *}$ & $(3.02)^{* * *}$ & $(2.87)^{* * *}$ \\
\hline \multirow[t]{2}{*}{ Saving deposits/assets } & -0.1483 & -0.0150 & 0.0789 & -0.1278 & -0.0091 & -0.0459 & -0.0039 & 0.0732 & -0.0365 & -0.0050 \\
\hline & $(1.87)^{*}$ & $(3.29)^{* * *}$ & $(21.04)^{* * *}$ & $(1.56)$ & $(2.00)^{* *}$ & $(3.36)^{* * *}$ & $(1.49)$ & $(22.75)^{* * *}$ & $(2.63)^{* * *}$ & $(1.88)^{*}$ \\
\hline \multirow[t]{2}{*}{ Fixed assets/assets } & -0.1463 & -0.0186 & -0.0023 & -0.1469 & -0.0186 & -0.0359 & -0.0032 & -0.0008 & -0.0359 & -0.0033 \\
\hline & $(4.92)^{* * *}$ & $(3.87)^{* * *}$ & $(0.71)$ & $(4.97)^{* * *}$ & $(3.96)^{* * *}$ & $(5.64)^{* * *}$ & $(2.59)^{* * *}$ & $(0.56)$ & $(5.64)^{* * *}$ & $(2.69)^{* * *}$ \\
\hline \multirow[t]{2}{*}{ Overhead costs/assets } & & & & -0.2593 & -0.0760 & & & & -0.1194 & 0.0151 \\
\hline & & & & $(1.34)$ & $(3.71)^{* * *}$ & & & & $(3.51)^{* * *}$ & $(2.56)^{* *}$ \\
\hline \multirow[t]{2}{*}{ Constant } & 0.0303 & 0.0230 & 0.0940 & 0.0547 & 0.0304 & -0.0107 & 0.0187 & 0.0480 & -0.0027 & 0.0174 \\
\hline & $(0.39)$ & $(2.39)^{* *}$ & $(6.19)^{* * *}$ & $(0.69)$ & $(3.32)^{* * *}$ & $(0.55)$ & $(4.90) * * *$ & $(10.45) * * *$ & $(0.13)$ & $(4.52)^{* * *}$ \\
\hline Observations & 4715 & 4720 & 4715 & 4715 & 4720 & 4809 & 4810 & 4820 & 4808 & 4810 \\
\hline R-squared & 0.08 & 0.06 & 0.25 & 0.08 & 0.07 & 0.08 & 0.10 & 0.38 & 0.09 & 0.10 \\
\hline
\end{tabular}

Panel B:

\section{Bridging the gap after 8 quarters?}

Federalized and Privatized

Privatized

Federalized

$0.0896 * * * \quad 0.0161 * * *$

$\begin{array}{llllllll}-0.044 * * * & -0.0006 * * * & -0.0009 * * * & -0.0441 * * * & -0.0006 * * * & -0.0108 * * * & 0.0012 * * * & -0.0001 * * *\end{array}$

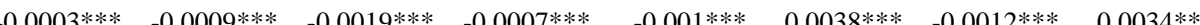

$-0.0048-0.0213^{* *}$

$-0.003 * * \quad-0.0042 * * * \quad-0.0031-0.0017$

$0.1118 * * * \quad 0.022 * * *$

Restructured

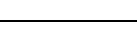

\section{Compare options after 8 quarters}

Privatized by federal vs. state govt

Federalized and privatized vs. restructured

$\begin{array}{rrr}0.0613 & 0.0159^{* *} & 0.0051 \\ 0.1263 & 0.0268^{* * *} & -0.0049 \\ 0.065 & 0.0109^{* *} & -0.01^{* * *} \\ -0.0207 & 0.0012 & -0.0057 \\ 0.0443 & 0.0121^{* * *} & -0.0157^{* * *}\end{array}$

$\begin{array}{rrrrr}0.0627 & 0.016^{* *} & 0.1237 * * * & 0.0229 * * * & -0.0005 \\ 0.1252 & 0.0262 * * * & 0.1254^{* * *} & 0.0309^{* * *} & -0.0065 \\ 0.0625 & 0.0102 * * & 0.0017 & 0.008^{* * *} & -0.006^{* *} \\ -0.0222 & 0.0006 & 0.0104 & -0.0042^{* *} & -0.0109 * * * \\ 0.0403 & 0.0108^{* *} & 0.0121 & 0.0038^{*} & -0.0169 * * *\end{array}$

$-0.0111 * * * \quad 0.0012^{* * *}$

$0.0037 * * * \quad-0.0013 * * *$

Privatized vs. restructured

Federalized vs. privatized

Federalized vs. restructured

$0.0443 \quad 0.0121^{* * *} \quad-0.0157^{* * *}$

$0.04030 .0108^{* *}$

0.0121

$-0.0044 * * *$

$-0.003$

T-statistics are reported in parentheses. *,**,*** indicate significance at the $10 \%, 5 \%$, and $1 \%$ level, respectively. The tests in the panel Bridging the gap test for the difference between (i) Eventually Federalized and Privatized and Federalized before Privatization plus Privatized after Federalization plus 8* Time since privatization after Federalization, (ii) Eventually Privatized and Privatized plus 8*Time since Privatization, (iii) Eventually Federalized and Federalized plus 8*Time since Federalization and (iv) Eventually Restructured and Restructured plus $8 *$ Time since Restructuring. The tests in the panel Compare options test for the difference between (i) Federalized before Privatization plus Privatized after Federalization plus $8 *$ Time since Privatization after Federalization and Privatized plus $8 *$ Time since Privatization, (ii) Federalized before Privatization plus Privatized after Federalization plus $8 *$ Time since Privatization after Federalization and Restructured plus $8 *$ Time since

Restructuring, (iii) Privatized plus 8*Time since Privatization and Restructured plus $8 *$ Time since Restructuring, (iv) Federalized plus 8*Time since Federalization and Privatized plus 8*Time since

Privatization, and (v) Federalized plus 8*Time since Federalization and Restructured plus 8*Time since Restructuring. 
Table 7: State bank transformation and performance: Robustness - clustered error terms.

\begin{tabular}{|c|c|c|c|c|c|c|c|c|c|c|}
\hline & $\begin{array}{l}\text { Return on } \\
\text { equity }\end{array}$ & $\begin{array}{l}\text { Return on } \\
\text { equity }\end{array}$ & $\begin{array}{l}\text { Return on } \\
\text { assets }\end{array}$ & $\begin{array}{l}\text { Return on } \\
\text { assets }\end{array}$ & $\begin{array}{l}\text { Overhead } \\
\text { costs/assets }\end{array}$ & $\begin{array}{l}\text { Overhead } \\
\text { costs/assets }\end{array}$ & $\begin{array}{l}\text { Return on } \\
\text { equity }\end{array}$ & $\begin{array}{l}\text { Return on } \\
\text { equity }\end{array}$ & $\begin{array}{l}\text { Return on } \\
\text { assets }\end{array}$ & $\begin{array}{l}\text { Return on } \\
\text { assets }\end{array}$ \\
\hline Assets & $\begin{array}{l}0.0034 \\
(0.48)\end{array}$ & $\begin{array}{l}0.0032 \\
(0.45)\end{array}$ & $\begin{array}{l}-0.0008 \\
(1.31)\end{array}$ & $\begin{array}{l}-0.0009 \\
(1.41)\end{array}$ & $\begin{array}{l}-0.0047 \\
(2.85)^{* * *}\end{array}$ & $\begin{array}{l}-0.0047 \\
(2.87)^{* * *}\end{array}$ & $\begin{array}{l}0.0022 \\
(0.30)\end{array}$ & $\begin{array}{l}0.0020 \\
(0.27)\end{array}$ & $\begin{array}{l}-0.0012 \\
(1.97)^{* *}\end{array}$ & $\begin{array}{l}-0.0012 \\
(2.07)^{* *}\end{array}$ \\
\hline Eventually Federalized and Privatized & $\begin{array}{l}-0.1575 \\
(3.89)^{* * *}\end{array}$ & $\begin{array}{l}-0.1581 \\
(3.93)^{* * *}\end{array}$ & $\begin{array}{l}-0.0151 \\
(7.43)^{* * *}\end{array}$ & $\begin{array}{l}-0.0152 \\
(7.67)^{* * *}\end{array}$ & $\begin{array}{l}0.0159 \\
(1.59)\end{array}$ & $\begin{array}{l}0.0159 \\
(1.58)\end{array}$ & $\begin{array}{l}-0.1533 \\
(3.85)^{* * *}\end{array}$ & $\begin{array}{l}-0.1540 \\
(3.88)^{* * *}\end{array}$ & $\begin{array}{l}-0.0136 \\
(6.16)^{* * *}\end{array}$ & $\begin{array}{l}-0.0138 \\
(6.34)^{* * *}\end{array}$ \\
\hline Federalized before Privatization & $\begin{array}{l}0.1462 \\
(3.49)^{* * * *}\end{array}$ & $\begin{array}{l}0.1465 \\
(3.53)^{* * *}\end{array}$ & $\begin{array}{l}0.0124 \\
(6.38)^{* * *}\end{array}$ & $\begin{array}{l}0.0124 \\
(6.69)^{* * *}\end{array}$ & $\begin{array}{l}-0.0053 \\
(0.52)\end{array}$ & $\begin{array}{l}-0.0051 \\
(0.50)\end{array}$ & $\begin{array}{l}0.1448 \\
(3.57)^{* * *}\end{array}$ & $\begin{array}{l}0.1452 \\
(3.60)^{* * *}\end{array}$ & $\begin{array}{l}0.0117 \\
(7.19)^{* * *}\end{array}$ & $\begin{array}{l}0.0118 \\
(7.48)^{* * * *}\end{array}$ \\
\hline Privatized after Federalization & $\begin{array}{l}0.0375 \\
(0.73)\end{array}$ & $\begin{array}{l}-0.1356 \\
(1.66)^{*}\end{array}$ & $\begin{array}{l}0.0079 \\
(1.21)\end{array}$ & $\begin{array}{l}-0.0227 \\
(1.38)\end{array}$ & $\begin{array}{l}-0.0040 \\
(0.83)\end{array}$ & $\begin{array}{l}-0.0038 \\
(0.25)\end{array}$ & $\begin{array}{l}0.0364 \\
(0.72)\end{array}$ & $\begin{array}{l}-0.1366 \\
(1.71)^{*}\end{array}$ & $\begin{array}{l}0.0075 \\
(1.19)\end{array}$ & $\begin{array}{l}-0.0231 \\
(1.47)\end{array}$ \\
\hline Time since privatization after federalization & & $\begin{array}{l}0.0296 \\
(4.76)^{* * *}\end{array}$ & & $\begin{array}{l}0.0052 \\
(3.11)^{* * *}\end{array}$ & & $\begin{array}{l}-0.0001 \\
(0.06)\end{array}$ & & $\begin{array}{l}0.0296 \\
(4.93)^{* * *}\end{array}$ & & $\begin{array}{l}0.0052 \\
(3.26)^{* * *}\end{array}$ \\
\hline Eventually Privatized & $\begin{array}{l}-0.2301 \\
(3.81)^{* * *}\end{array}$ & $\begin{array}{l}-0.2304 \\
(3.81)^{* * *}\end{array}$ & $\begin{array}{l}-0.0159 \\
(5.88)^{* * *}\end{array}$ & $\begin{array}{l}-0.0160 \\
(5.87)^{* * *}\end{array}$ & $\begin{array}{l}0.0139 \\
(2.47)^{* *}\end{array}$ & $\begin{array}{l}0.0139 \\
(2.46)^{* *}\end{array}$ & $\begin{array}{l}-0.2264 \\
(3.76)^{* * *}\end{array}$ & $\begin{array}{l}-0.2268 \\
(3.77)^{* * *}\end{array}$ & $\begin{array}{l}-0.0148 \\
(5.59)^{* * *}\end{array}$ & $\begin{array}{l}-0.0149 \\
(5.60)^{* * *}\end{array}$ \\
\hline Privatized & $\begin{array}{l}0.1913 \\
(2.65)^{* * *}\end{array}$ & $\begin{array}{l}0.1704 \\
(2.14)^{* *}\end{array}$ & $\begin{array}{l}0.0174 \\
(10.00)^{* * *}\end{array}$ & $\begin{array}{l}0.0082 \\
(1.61)\end{array}$ & $\begin{array}{l}-0.0178 \\
(2.59)^{* *}\end{array}$ & $\begin{array}{l}-0.0052 \\
(0.75)\end{array}$ & $\begin{array}{l}0.1866 \\
(2.60)^{* * *}\end{array}$ & $\begin{array}{l}0.1691 \\
(2.13)^{* *}\end{array}$ & $\begin{array}{l}0.0160 \\
(8.96)^{* * *}\end{array}$ & $\begin{array}{l}0.0079 \\
(1.59)\end{array}$ \\
\hline Time since privatization & & $\begin{array}{l}0.0020 \\
(1.07)\end{array}$ & & $\begin{array}{l}0.0009 \\
(2.42)^{* *}\end{array}$ & & $\begin{array}{l}-0.0012 \\
(6.95)^{* * *}\end{array}$ & & $\begin{array}{l}0.0017 \\
(0.89)\end{array}$ & & $\begin{array}{l}0.0008 \\
(2.14)^{* *}\end{array}$ \\
\hline Eventually Federalized & $\begin{array}{l}-0.1659 \\
(2.25)^{* *}\end{array}$ & $\begin{array}{l}-0.1660 \\
(2.25)^{* *}\end{array}$ & $\begin{array}{l}-0.0175 \\
(5.37)^{* * *}\end{array}$ & $\begin{array}{l}-0.0175 \\
(5.35)^{* * *}\end{array}$ & $\begin{array}{l}0.0186 \\
(4.64)^{* * *}\end{array}$ & $\begin{array}{l}0.0186 \\
(4.60)^{* * *}\end{array}$ & $\begin{array}{l}-0.1609 \\
(2.23)^{* *}\end{array}$ & $\begin{array}{l}-0.1612 \\
(2.23)^{* *}\end{array}$ & $\begin{array}{l}-0.0158 \\
(5.04)^{* * *}\end{array}$ & $\begin{array}{l}-0.0159 \\
(5.05)^{* * *}\end{array}$ \\
\hline Federalized & $\begin{array}{l}0.1639 \\
(2.68)^{* * *}\end{array}$ & $\begin{array}{l}0.1273 \\
(1.82)^{*}\end{array}$ & $\begin{array}{l}0.0164 \\
(7.45)^{* * *}\end{array}$ & $\begin{array}{l}0.0086 \\
(3.51)^{* * *}\end{array}$ & $\begin{array}{l}-0.0198 \\
(4.06)^{* * *}\end{array}$ & $\begin{array}{l}-0.0077 \\
(1.65)\end{array}$ & $\begin{array}{l}0.1586 \\
(2.61)^{* * *}\end{array}$ & $\begin{array}{l}0.1253 \\
(1.78)^{*}\end{array}$ & $\begin{array}{l}0.0146 \\
(7.52)^{* * *}\end{array}$ & $\begin{array}{l}0.0077 \\
(3.43)^{* * *}\end{array}$ \\
\hline Time since Federalization & & $\begin{array}{l}0.0048 \\
(1.93)^{*}\end{array}$ & & $\begin{array}{l}0.0010 \\
(4.19)^{* * *}\end{array}$ & & $\begin{array}{l}-0.0016 \\
(2.89)^{* * *}\end{array}$ & & $\begin{array}{l}0.0044 \\
(1.74)^{*}\end{array}$ & & $\begin{array}{l}0.0009 \\
(3.79)^{* * *}\end{array}$ \\
\hline Eventually Restructured & $\begin{array}{l}-0.1416 \\
(1.24)\end{array}$ & $\begin{array}{l}-0.1414 \\
(1.24)\end{array}$ & $\begin{array}{l}-0.0071 \\
(1.81)^{*}\end{array}$ & $\begin{array}{l}-0.0071 \\
(1.82)^{*}\end{array}$ & $\begin{array}{l}0.0001 \\
(0.02)\end{array}$ & $\begin{array}{l}-0.0000 \\
(0.01)\end{array}$ & $\begin{array}{l}-0.1415 \\
(1.25)\end{array}$ & $\begin{array}{l}-0.1415 \\
(1.25)\end{array}$ & $\begin{array}{l}-0.0071 \\
(1.97)^{* *}\end{array}$ & $\begin{array}{l}-0.0071 \\
(1.97)^{* *}\end{array}$ \\
\hline Restructured & $\begin{array}{l}0.1309 \\
(1.25)\end{array}$ & $\begin{array}{l}0.0886 \\
(0.82)\end{array}$ & $\begin{array}{l}0.0046 \\
(1.46)\end{array}$ & $\begin{array}{l}0.0037 \\
(1.37)\end{array}$ & $\begin{array}{l}-0.0045 \\
(0.90)\end{array}$ & $\begin{array}{l}-0.0048 \\
(0.83)\end{array}$ & $\begin{array}{l}0.1297 \\
(1.24)\end{array}$ & $\begin{array}{l}0.0874 \\
(0.81)\end{array}$ & $\begin{array}{l}0.0042 \\
(1.44)\end{array}$ & $\begin{array}{l}0.0033 \\
(1.31)\end{array}$ \\
\hline Time since restructuring & & $\begin{array}{l}0.0041 \\
(2.55)^{* *}\end{array}$ & & $\begin{array}{l}0.0001 \\
(0.95)\end{array}$ & & $\begin{array}{l}0.0000 \\
(0.08)\end{array}$ & & $\begin{array}{l}0.0041 \\
(2.55)^{* *}\end{array}$ & & $\begin{array}{l}0.0001 \\
(0.98)\end{array}$ \\
\hline Federal bank & $\begin{array}{l}-0.0917 \\
(2.81)^{* * *}\end{array}$ & $\begin{array}{l}-0.0917 \\
(2.82)^{* * *}\end{array}$ & $\begin{array}{l}-0.0046 \\
(2.61)^{* * *}\end{array}$ & $\begin{array}{l}-0.0046 \\
(2.63)^{* * *}\end{array}$ & $\begin{array}{l}0.0095 \\
(3.11)^{* * *}\end{array}$ & $\begin{array}{l}0.0094 \\
(3.10)^{* * *}\end{array}$ & $\begin{array}{l}-0.0892 \\
(2.68)^{* * *}\end{array}$ & $\begin{array}{l}-0.0892 \\
(2.68)^{* * *}\end{array}$ & $\begin{array}{l}-0.0039 \\
(2.18)^{* *}\end{array}$ & $\begin{array}{l}-0.0039 \\
(2.20)^{* *}\end{array}$ \\
\hline Foreign-owned bank & $\begin{array}{l}-0.0419 \\
(2.39)^{* *}\end{array}$ & $\begin{array}{l}-0.0418 \\
(2.39)^{* *}\end{array}$ & $\begin{array}{l}-0.0047 \\
(3.85)^{* * *}\end{array}$ & $\begin{array}{l}-0.0047 \\
(3.85)^{* * *}\end{array}$ & $\begin{array}{l}-0.0025 \\
(1.37)\end{array}$ & $\begin{array}{l}-0.0025 \\
(1.36)\end{array}$ & $\begin{array}{l}-0.0425 \\
(2.44)^{* *}\end{array}$ & $\begin{array}{l}-0.0425 \\
(2.44)^{* *}\end{array}$ & $\begin{array}{l}-0.0049 \\
(3.99)^{* * *}\end{array}$ & $\begin{array}{l}-0.0049 \\
(3.99)^{* * *}\end{array}$ \\
\hline
\end{tabular}




\begin{tabular}{|c|c|c|c|c|c|c|c|c|c|c|}
\hline & $\begin{array}{l}\text { Return on } \\
\text { equity }\end{array}$ & $\begin{array}{l}\text { Return on } \\
\text { equity }\end{array}$ & $\begin{array}{l}\text { Return on } \\
\text { assets }\end{array}$ & $\begin{array}{l}\text { Return on } \\
\text { assets }\end{array}$ & $\begin{array}{l}\text { Overhead } \\
\text { costs/assets }\end{array}$ & $\begin{array}{l}\text { Overhead } \\
\text { costs/assets }\end{array}$ & $\begin{array}{l}\text { Return on } \\
\text { equity }\end{array}$ & $\begin{array}{l}\text { Return on } \\
\text { equity }\end{array}$ & $\begin{array}{l}\text { Return on } \\
\text { assets }\end{array}$ & $\begin{array}{l}\text { Return on } \\
\text { assets }\end{array}$ \\
\hline Not participating state bank & $\begin{array}{l}-0.0150 \\
(0.69)\end{array}$ & $\begin{array}{l}-0.0148 \\
(0.68)\end{array}$ & $\begin{array}{l}-0.0028 \\
(2.02)^{* *}\end{array}$ & $\begin{array}{l}-0.0027 \\
(2.10)^{* *}\end{array}$ & $\begin{array}{l}0.0156 \\
(6.32)^{* * * *}\end{array}$ & $\begin{array}{l}0.0154 \\
(6.60)^{* * *}\end{array}$ & $\begin{array}{l}-0.0109 \\
(0.50)\end{array}$ & $\begin{array}{l}-0.0108 \\
(0.49)\end{array}$ & $\begin{array}{l}-0.0015 \\
(1.10)\end{array}$ & $\begin{array}{l}-0.0015 \\
(1.13)\end{array}$ \\
\hline Saving deposits/assets & $\begin{array}{l}-0.1467 \\
(1.27)\end{array}$ & $\begin{array}{l}-0.1483 \\
(1.29)\end{array}$ & $\begin{array}{l}-0.0146 \\
(2.17)^{* *}\end{array}$ & $\begin{array}{l}-0.0150 \\
(2.43)^{* *}\end{array}$ & $\begin{array}{l}0.0778 \\
(6.53)^{* * * *}\end{array}$ & $\begin{array}{l}0.0789 \\
(7.20)^{* * * *}\end{array}$ & $\begin{array}{l}-0.1260 \\
(1.09)\end{array}$ & $\begin{array}{l}-0.1278 \\
(1.10)\end{array}$ & $\begin{array}{l}-0.0085 \\
(1.33)\end{array}$ & $\begin{array}{l}-0.0091 \\
(1.51)\end{array}$ \\
\hline Fixed assets/assets & $\begin{array}{l}-0.1461 \\
(2.31)^{* *}\end{array}$ & $\begin{array}{l}-0.1463 \\
(2.32) * *\end{array}$ & $\begin{array}{l}-0.0185 \\
(1.80)^{*}\end{array}$ & $\begin{array}{l}-0.0186 \\
(1.80)^{*}\end{array}$ & $\begin{array}{l}-0.0023 \\
(0.26)\end{array}$ & $\begin{array}{l}-0.0023 \\
(0.26)\end{array}$ & $\begin{array}{l}-0.1468 \\
(2.34)^{* *}\end{array}$ & $\begin{array}{l}-0.1469 \\
(2.34)^{* *}\end{array}$ & $\begin{array}{l}-0.0186 \\
(1.83)^{*}\end{array}$ & $\begin{array}{l}-0.0186 \\
(1.83)^{*}\end{array}$ \\
\hline Overhead costs/assets & & & & & & & $\begin{array}{l}-0.2655 \\
(1.28)\end{array}$ & $\begin{array}{l}-0.2593 \\
(1.25)\end{array}$ & $\begin{array}{l}-0.0786 \\
(2.30)^{* *}\end{array}$ & $\begin{array}{l}-0.0760 \\
(2.24)^{* *}\end{array}$ \\
\hline Constant & $\begin{array}{l}0.0262 \\
(0.22)\end{array}$ & $\begin{array}{l}0.0303 \\
(0.26)\end{array}$ & $\begin{array}{l}0.0223 \\
(2.06)^{* *}\end{array}$ & $\begin{array}{l}0.0230 \\
(2.18)^{* *}\end{array}$ & $\begin{array}{l}0.0938 \\
(3.15)^{* * *}\end{array}$ & $\begin{array}{l}0.0940 \\
(3.16)^{* * *}\end{array}$ & $\begin{array}{l}0.0511 \\
(0.42)\end{array}$ & $\begin{array}{l}0.0547 \\
(0.45)\end{array}$ & $\begin{array}{l}0.0299 \\
(2.82)^{* * *}\end{array}$ & $\begin{array}{l}0.0304 \\
(2.93)^{* * *}\end{array}$ \\
\hline Observations & 4715 & 4715 & 4720 & 4720 & 4715 & 4715 & 4715 & 4715 & 4720 & 4720 \\
\hline R-squared & 0.08 & 0.08 & 0.06 & 0.06 & 0.25 & 0.25 & 0.08 & 0.08 & 0.07 & 0.07 \\
\hline
\end{tabular}




\section{Appendix A: Sources and Procedures for Constructing Measures of Partisan Influence}

Section 3 and Table 3 assess the bank transformation decision taken by states partly in terms of partisan political ties between each state's key elected officials and the national executive. Two types of ties are considered: membership in the president's political party (the PSDB), and membership in any one of the parties making up the president's ruling coalition. ${ }^{43}$ Three classes of elected officials from each state are taken into account: the state governor, members of the state's delegation to the federal Chamber of Deputies, and members of the state's delegation to the federal Senate. Sources indicating office holders and their party membership are varied, but most accessibly summarized in Nicolau (2002). Governors who served from 1995 through 1998 would have been those involved in the bulk of the transformation decisions, and their party affiliations were employed in constructing dichotomous variables indicating membership in the PSDB, and membership in Cardoso's coalition. Similarly, variables taking into account the share of each state's cohort of federal deputies serving from 1995 through 1998 who were members of the PSDB, and members of the president's coalition, were constructed. Unlike governors and deputies, senators in Brazil are elected for eight-year terms. Senatorial elections are staggered in such a way that one senator from each state is elected, then four years later two others are elected. Those senators sitting from 1995 through 1998 (some of whom were elected in 1990 , the others in 1994) were used in creating measures of the proportion of each state's senate delegation with membership in the PSDB, and the presidential coalition. In all cases of office holders the slightly broader definition of the presidential coalition, which applied from early 1996 onward, was employed.

\footnotetext{
${ }^{43}$ Amorim Neto reports the President's coalition from January 1995 until April 1996 was made up of four parties: PSDB, PMDB, PFL, and PTC. In April 1996 two more parties joined the coalition (the PPB and PPS); Amorim Neto (2002).
} 


\section{Appendix Table B: Variable definitions and sources}

\begin{tabular}{|c|c|c|}
\hline Variable name & Definition & Primary Source \\
\hline Transformation & $\begin{array}{l}1 \text { if the state bank was } \\
\text { liquidated, } 2 \text { if the federal } \\
\text { government took it over, } 3 \\
\text { if the state government } \\
\text { privatized it; } 4 \text { if the bank } \\
\text { was restructured and stayed } \\
\text { in government ownership. }\end{array}$ & $\begin{array}{l}\text { Folha de São Paulo and } \\
\text { Estado de São Paulo are the } \\
\text { main sources. Compare } \\
\text { Table } 2 \text {. }\end{array}$ \\
\hline DFI & $\begin{array}{l}\text { Dummy variable that takes } \\
\text { on value one if state } \\
\text { established a development } \\
\text { agency }\end{array}$ & Banco Central do Brasil \\
\hline RAET & $\begin{array}{l}\text { Dummy variable that takes } \\
\text { on value one if the state } \\
\text { bank was taken over by the } \\
\text { federal government under } \\
\text { the RAET }\end{array}$ & Banco Central do Brasil \\
\hline Share of transfers & $\begin{array}{l}\text { Share of transfers from } \\
\text { federal government in state } \\
\text { revenues, averaged over } \\
1995 \text { to } 2000 \text {. }\end{array}$ & Ministerio da Fazenda \\
\hline Deficit/GDP & $\begin{array}{l}\text { Ratio of state budget deficit } \\
\text { to state GDP averaged over } \\
1995 \text { to } 2000 \text {. }\end{array}$ & Ministerio da Fazenda \\
\hline Poverty rate & $\begin{array}{l}\text { Share of population living } \\
\text { below the poverty line } \\
\text { averaged over } 1995 \text { to } 2000\end{array}$ & IPEA \\
\hline GDP per capita & $\begin{array}{l}\text { GDP per capita averaged } \\
\text { over } 1995 \text { to } 2000\end{array}$ & IBGE \\
\hline $\begin{array}{l}\text { Share of agricultural } \\
\text { production }\end{array}$ & $\begin{array}{l}\text { Share of agricultural } \\
\text { production in state GDP } \\
\text { averaged over } 1995 \text { to } 2000\end{array}$ & IBGE \\
\hline Return on equity & $\begin{array}{l}\text { Profits divided by total } \\
\text { equity }\end{array}$ & Banco Central do Brasil \\
\hline Return on assets & $\begin{array}{l}\text { Profits divided by total } \\
\text { assets }\end{array}$ & Banco Central do Brasil \\
\hline Overhead costs/Assets & $\begin{array}{l}\text { Total overhead costs } \\
\text { divided by total assets }\end{array}$ & Banco Central do Brasil \\
\hline Assets & $\begin{array}{l}\text { Total assets in constant } \\
\text { million Reais, deflated by } \\
\text { CPI }\end{array}$ & Banco Central do Brasil \\
\hline Savings deposits/assets & $\begin{array}{l}\text { Savings deposit divided by } \\
\text { total assets }\end{array}$ & Banco Central do Brasil \\
\hline Fixed assets/assets & $\begin{array}{l}\text { Fixed assets divided by } \\
\text { total assets }\end{array}$ & Banco Central do Brasil \\
\hline $\begin{array}{l}\text { Eventually Federalized and } \\
\text { Privatized }\end{array}$ & $\begin{array}{l}\text { Dummy variable that takes } \\
\text { on value one for all banks }\end{array}$ & Banco Central do Brasil \\
\hline
\end{tabular}




\begin{tabular}{|c|c|c|}
\hline & $\begin{array}{l}\text { during the whole sample } \\
\text { period that were federalized } \\
\text { and privatized during the } \\
\text { sample period }\end{array}$ & \\
\hline Eventually Federalized & $\begin{array}{l}\text { Dummy variable that takes } \\
\text { on value one for all banks } \\
\text { during the whole sample } \\
\text { period that were } \\
\text { federalized, but not } \\
\text { privatized during the } \\
\text { sample period }\end{array}$ & Banco Central do Brasil \\
\hline Eventually Restructured & $\begin{array}{l}\text { Dummy variable that takes } \\
\text { on value one for all banks } \\
\text { during the whole sample } \\
\text { period that were } \\
\text { restructured during the } \\
\text { sample period }\end{array}$ & Banco Central do Brasil \\
\hline Eventually Privatized & $\begin{array}{l}\text { Dummy variable that takes } \\
\text { on value one for all banks } \\
\text { during the whole sample } \\
\text { period that were privatized } \\
\text { by the state government } \\
\text { during the sample period }\end{array}$ & Banco Central do Brasil \\
\hline $\begin{array}{l}\text { Federalized before } \\
\text { Privatization }\end{array}$ & $\begin{array}{l}\text { Dummy variable that takes } \\
\text { on value one in the quarter } \\
\text { when a bank that is } \\
\text { subsequently privatized is } \\
\text { federalized and all } \\
\text { following quarters }\end{array}$ & Banco Central do Brasil \\
\hline $\begin{array}{l}\text { Privatized after } \\
\text { federalization }\end{array}$ & $\begin{array}{l}\text { Dummy variable that takes } \\
\text { on value one in the quarter } \\
\text { when a federalized bank is } \\
\text { privatized and all following } \\
\text { quarters }\end{array}$ & Banco Central do Brasil \\
\hline Privatized & $\begin{array}{l}\text { Dummy variable that takes } \\
\text { on value one in the quarter } \\
\text { when a bank is privatized } \\
\text { by the state government and } \\
\text { all following quarters }\end{array}$ & Banco Central do Brasil \\
\hline Restructured & $\begin{array}{l}\text { Dummy variable that takes } \\
\text { on value one in the quarter } \\
\text { when a bank is restructured } \\
\text { ed by the state government } \\
\text { and all following quarters. } \\
\text { The timing is determined by } \\
\text { the time when contract was } \\
\text { approved by Federal Senate }\end{array}$ & Banco Central do Brasil \\
\hline Federalized & $\begin{array}{l}\text { Dummy variable that takes } \\
\text { on value one in the quarter }\end{array}$ & Banco Central do Brasil \\
\hline
\end{tabular}




\begin{tabular}{|c|c|c|}
\hline & $\begin{array}{l}\text { when a bank that has not } \\
\text { been privatized in the } \\
\text { sample period is federalized } \\
\text { and all following quarters }\end{array}$ & \\
\hline $\begin{array}{l}\text { Time since privatization } \\
\text { after federalization }\end{array}$ & $\begin{array}{l}\text { Number of quarters since a } \\
\text { federalized bank has been } \\
\text { privatized }\end{array}$ & Banco Central do Brasil \\
\hline Time since privatization & $\begin{array}{l}\text { Number of quarters since a } \\
\text { bank has been privatized by } \\
\text { state government }\end{array}$ & Banco Central do Brasil \\
\hline Time since restructuring & $\begin{array}{l}\text { Number of quarters since a } \\
\text { bank has started the process } \\
\text { of restructuring }\end{array}$ & Banco Central do Brasil \\
\hline Time since federalization & $\begin{array}{l}\text { Number of quarters since a } \\
\text { bank that has not been } \\
\text { privatized in the sample } \\
\text { period has been federalized }\end{array}$ & Banco Central do Brasil \\
\hline Non participating state bank & $\begin{array}{l}\text { Dummy variable that takes } \\
\text { on value one for state banks } \\
\text { that did not participate in } \\
\text { PROES }\end{array}$ & Banco Central do Brasil \\
\hline Federal bank & $\begin{array}{l}\text { Dummy variable that takes } \\
\text { on value one for banks that } \\
\text { are owned by the federal } \\
\text { government }\end{array}$ & Banco Central do Brasil \\
\hline Foreign-owned bank & $\begin{array}{l}\text { Dummy variable that takes } \\
\text { on value one for banks that } \\
\text { are majority owned by } \\
\text { foreigners }\end{array}$ & Banco Central do Brasil \\
\hline
\end{tabular}

